\title{
Newton, Goethe e Schopenhauer sobre as cores: entre qualidade e quantidade ${ }^{*}$
}

\author{
Newton, Goethe and Schopenhauer on the colors: \\ between quality and quantity
}

\author{
Gabriel Valladão Silva \\ Doutorando em Filosofia pela Universidade de Campinas (UNICAMP) \\ E-mail: gvalladao@gmail.com
}

\begin{abstract}
Resumo: 0 artigo busca traçar um panorama dos encadeamentos entre as reflexões de Newton, Goethe e Schopenhauer sobre as cores, com a intenção de situá-las na história do pensamento sobre o tema. Para tal, tomamos como fio condutor filosófico da análise a relação entre quantidade e qualidade, a qual é representada de distintas maneiras nos diferentes autores quando estes tratam do fenômeno das cores.
\end{abstract}

Palavras-chave: Newton; Goethe; Schopenhauer; Cores; Quantidade e qualidade.
Abstract: This paper intends to trace a panorama of the relations between the observations of Newton, Goethe and Schopenhauer on colors, and to situate them in the history of thought on the subject. To that end, we take as a philosophical leitmotif of our analysis the relation between quantity and quality, which is represented in different ways within the works of these authors regarding the theory of color.

Keywords: Newton; Goethe; Schopenhauer; Colors; Quantity and quality.

\footnotetext{
* Comunicação apresentada durante o VII Colóquio Internacional Schopenhauer, ocorrido na Universidade Federal da Bahia (UFBA), em Salvador, de 26 a 30 de outubro de 2015.
} 
presente trabalho tem um duplo objetivo, isto é, ele busca prestar, simultaneamente, em um mesmo texto, dois serviços distintos à comunidade schopenhaueriana (e por que não filosófica) brasileira.

Por um lado, trata-se para nós de buscar compreender e reproduzir, para o público brasileiro, o debate sobre o fenômeno das cores e sua percepção no qual se insere o trabalho Sobre a visão e as cores de Schopenhauer. Embora a obra já possua tradução em nossa língua desde 2005, realizada por Erlon José Paschoal para a Editora Nova Alexandria, a bibliografia a seu respeito no Brasil é quase nula. Por isso cremos ser pertinente demorarmo-nos na exposição das reflexões não apenas de Schopenhauer, mas também de Newton e Goethe sobre as cores, buscando reproduzir, pelo maior número de perspectivas possível, a discussão em que estes dois pensadores aparecem como os principais interlocutores do filósofo. Ao final buscaremos traçar um breve panorama acerca das transformações e inovações pelas quais o pensamento sobre as cores passou desde então, e ressaltar a relevância de Schopenhauer, Goethe e Newton na história das interpretações desse fenômeno.

Contudo, antes de mais nada, quero já de início ressaltar a grande dificuldade que há em estabelecer um diálogo entre obras de conteúdo e recepção tão díspares como as três que abordamos aqui.

Para a doutrina das cores de Goethe é louvada por seu valor artístico (tanto intrínseco, em sua composição, como técnico, com vistas à prática da pintura e da coloração - mas também em sentido pejorativo, como valor meramente decorativo ou para decoradores ${ }^{1}$ ) e por ter apontado uma ou outra característica dos fenômenos de cores que até então passara despercebida (especialmente os fenômenos fisiológicos da visão); no todo, porém, essa grandiosa obra costuma ser posta de lado benevolamente como um "erro genial" - para utilizar aqui a expressão de Schopenhauer em seu juízo sobre a teoria evolutiva de Lamarck - ou então, para usar locução mais forte, como um "erro belo", resultado da intromissão indevida de uma mente poética no âmbito da ciência.

Já a obra do próprio Schopenhauer, Sobre a visão e as cores, raramente é lembrada fora do círculo dos estudiosos de sua filosofia, e mesmo dentro do

${ }^{1}$ Cf. SAFRANSKI, R. Schopenhauer und die wilden Jahre der Philosophie, p. 269; SILVA, J. C. S. P. A. A gramática das cores em Wittgenstein, p. 269 s., 273 s. 
mesmo ocupa via de regra uma posição subalterna. 0 próprio filósofo consideravaa um escrito secundário no interior de sua $\mathrm{obra}^{2}$, o que contribuiu para que permanecesse fora do foco de atenção não apenas dos interessados na questão da luz, da visão e das cores em geral, mas também daqueles que se dedicam ao estudo do pensamento schopenhaueriano.

Por fim, a Ótica de Newton aparece coberta de prestígio até os dias de hoje, como a base (mesmo que retrabalhada em muitos aspectos) do entendimento da luz e das cores que é até o presente julgado como sendo o cientificamente correto, assim como para as descobertas posteriores nesse campo - e certamente não sem razão. A grande obra de Newton, que guarda uma estreita relação com seus Princípios matemáticos da filosofia da natureza (não apenas a nível do método, mas também por vezes no que diz respeito ao conteúdo 3 ), apresenta-se ao leitor com uma linguagem clara e uma profusão de elaborações matemáticas dos fenômenos que buscam elevá-los a casos de leis gerais, e consiste, em sua maioria, em descrições de experimentos que podem ser reproduzidos e aprimorados pelas gerações vindouras. A obra de Newton, que se encerra, no terceiro livro, com uma série de questões e propostas de investigação, convida ativamente o leitor a continuar seu trabalho, a avançar na ciência por ele inaugurada.

É preciso, no entanto, deixar claro já de antemão que não nos proporemos a comparar essas três obras quanto ao seu valor "científico" (isto é, com vistas à perspectiva hodierna acerca do que é considerado científico), já que nem mesmo teríamos qualquer competência para tal. 0 segundo objetivo deste trabalho, que, ao mesmo tempo que extrapola uma mera exegese do texto schopenhaueriano e de seus interlocutores, fornece-nos também um fio condutor para levá-la a cabo, consiste, muito antes, em reavivar e evidenciar um diálogo filosófico que ocorre entre seus autores, para o qual a teoria das cores sem dúvida dá a ocasião, mas que, ao mesmo tempo, se estende para além dela, revelando visões de mundo muito distintas, embora ligadas entre si em diversos pontos.

\footnotetext{
${ }^{2}$ Nas recomendações à edição de suas obras, Schopenhauer afirma ser desnecessário incluir nela o trabalho sobre as cores. Já em sua correspondência com Goethe, contemporânea à redação da obra, Schopenhauer oscila entre manifestações de forte apreço por sua teoria das cores (cf. SCHOPENHAUER, A. Der Briefwechsel, carta 172 - 3 de Setembro de 1815) e de menosprezo em relação à mesma (cf. idem, carta 176 - 11 de Novembro de 1815).

${ }^{3}$ Cf. p. ex. NEWTON, I. Optics, pp. 521, 531, 536 ss.
} 
De maneira geral, tomamos aqui a discussão sobre a luz, a visão e as cores como um pretexto para trazer à tona um debate filosófico mais profundo que se oculta sob as diferentes interpretações desses autores sobre os mencionados fenômenos, a saber: o antigo debate sobre a relação entre quantidade e qualidade na constituição de nossa experiência e de nosso conhecimento. A teoria das cores é especialmente adequada para isso porque estas constituem não um objeto dessa experiência propriamente dito, mas antes um elemento constitutivo da mesma, o qual, não obstante, diferentemente de sua porção puramente formal, passível de tratamento matemático, não pode ser separado de seus objetos. Diferentemente desses outros aspectos formais da experiência - tais como o número, a forma etc. -, a cor aparece imediatamente para nós (e nisso os autores aqui tratados são unânimes) como qualidade. Isto, porém, produz, no contexto moderno, o problema da elaboração de um método adequado para a ciência sobre esse fenômeno, e, com ele, uma série de questões de teor propriamente filosófico: será possível uma ciência do puramente qualitativo, ou será preciso reconduzi-lo à quantidade? Como realizar essa recondução? Será ela possível? Qual a relação entre quantidade e qualidade?

Veremos como cada autor abordado tem sua própria resposta à questão, que revela, atrás de si, uma concepção peculiar da natureza, do sujeito, e da experiência que esse sujeito tem da natureza. Desse modo, como dito, a teoria das cores leva-nos, por uma via peculiar, ao âmago propriamente filosófico dos pensamentos de Newton, Goethe e Schopenhauer e - por que não - também de nossa própria perspectiva contemporânea sobre o mundo, a qual, conforme veremos, ainda carrega fortes influências desses pensadores.

\section{Newton}

a) Em busca de um modelo para a quantificação do fenômeno das cores

A Ótica de Newton enquadra-se perfeitamente no espírito de sua época; sim, podemos dizer que ela é em grande medida uma das obras canônicas do objetivismo fisicalista moderno, cujos efeitos na ciência se estendem até os dias de hoje. Essa postura fundamental que perpassa o mencionado escrito condiciona uma importante característica sua: nela, Newton não está interessado nas cores em 
si, as quais já haviam sido denunciadas como fenômenos psicológicos por Locke, que as incluiu sob a rubrica das "qualidades secundárias" e, portanto, subjetivas, dos objetos da experiência, opostas às "qualidades primárias" que seriam essenciais aos objetos e das quais depende sua apreensão por meio de modelos matemáticos. Newton, como representante do espírito de sua época, dedica, assim, seus esforços à elucidação dos fenômenos objetivos que fundamentariam a sensação propriamente dita. Ele mesmo afirma reiteradas vezes e com toda clareza que não pretende tratar das próprias cores tomadas em si, mas dos raios que supostamente causariam as sensações de cores ao atingir nosso "sensório" [sensory; sensorium]. Em outras palavras, ele busca elucidar o fenômeno objetivo por detrás de nossa percepção visual, sua causa no mundo exterior espaçotemporal4 ${ }^{4}$ É no início da Ótica que Newton formula, pela primeira vez, a máxima que se tornou célebre na versão do "escólio geral" à segunda edição dos Princípios matemáticos da filosofia da natureza: hypotheses non fingo ("não forjo hipóteses"): "Meu projeto neste livro não é explicar as propriedades da luz por meio de hipóteses, mas propor e prová-las por meio da razão e de experimentos"5.

As relações de que Newton trata não ocorrem, portanto, entre as cores tomadas em si e propriamente, mas entre os raios de luz que, diferentemente das aparições em nosso "sensório", podem ser medidos e calculados geometricamente, sendo distinguidos, conforme descobre Newton em seus experimentos, segundo seus ângulos de refratabilidade, os quais corresponderiam à sensação das diversas cores. Newton pretende desenvolver um método geométrico para medir essa refração dos raios de luz e, assim, estabelecer, com base na proporção entre os fenômenos luminosos que são causas das cores que percebemos, uma

\footnotetext{
${ }^{4}$ Cf. NEWTON, I. Optics, p. 428: "se em qualquer momento eu falar da luz e dos raios como coloridos ou imbuídos de cores, quero que se entenda que não falo filosófica e propriamente, mas de maneira grosseira (...). Pois os raios, para falar propriamente, não são coloridos. Neles nada mais há além de um certo poder e uma disposição para excitar uma sensação desta ou daquela cor. (...) [C]ores no objeto nada mais são que uma disposição para refletir este ou aquele tipo de raios mais copiosamente que o resto; nos raios nada mais são que suas disposições para propagar este ou aquele movimento para dentro do sensório, e no sensório são sensações desses movimentos sob a forma de cores". Cf. também idem, pp. 443, 478. - As traduções de obras citadas a partir do original foram feitas por mim. Inseri o termo original entre colchetes no caso de termos relevantes e/ou de difícil tradução.

${ }^{5}$ NEWTON, I. Optics, p. 379. Cf. idem, p. 493, 528: “a principal ocupação da filosofia natural é argumentar a partir dos fenômenos sem forjar hipóteses, e deduzir causas a partir de efeitos".
} 
proporcionalidade objetiva - embora indireta - entre estas últimas ${ }^{6}$; seu interesse, assim como no caso de seu estudo sobre a gravidade, volta-se para a calculabilidade dos fenômenos óticos - calculabilidade esta que dependeria de uma apreensão puramente objetiva dos mesmos, isto é, da redução de seu status qualitativo a alguma forma quantificável.

Para tal, ele busca estabelecer um padrão de medida, pensado em analogia com as sete notas musicais, a partir do qual se pudesse determinar as proporções matemáticas entre os diferentes raios que causam as sensações de cores em nós ${ }^{7}$. Portanto, a divisão do espectro das cores em sete - criticada duramente por Schopenhauer - não reflete necessariamente para Newton uma proporção objetivamente existente na natureza, mas é antes apenas uma convenção para que se possa estabelecer medidas e proporções matemáticas ${ }^{8}$. Trata-se, como dito, de um mero padrão de medida, uma referência arbitrária a partir da qual se tornaria possível medir relativamente as mais variadas aparições de cores, comparável ao sistema métrico ou à divisão do tempo em minutos e segundos. 0 mesmo vale para todas as relações matemáticas que ele pretende encontrar nos fenômenos da luz e das cores ${ }^{9}$.

\section{b) Luz como corpúsculo}

Munido dessa proposta de uma compreensão verdadeiramente matemática das cores - o que, de seu ponto de vista, condicionaria uma visão científica das mesmas -, Newton avança, na terceira parte do segundo livro da Ótica, para a construção de um modelo que permita reconduzir o fenômeno das cores, que em nosso "sensório" subjetivo aparece como algo puramente qualitativo, a um fenômeno objetivo, material, e, portanto, quantificável. Esse modelo é alcançado na quinta proposição da mencionada parte, a qual afirma que "As partes transparentes

\footnotetext{
${ }^{6}$ Cf. idem, Prop. 1, Teorema 1 (p. 386): “Luzes que diferem em cor diferem também em graus de refratabilidade".

${ }^{7}$ Cf. idem, p. 429,440 s., 464 s.

8 Cf. p. ex. idem, p. 394, 404, 427, onde o autor afirma que há de fato inúmeras cores, correspondentes aos inúmeros graus de refratabilidade possíveis dos raios de luz.

${ }^{9}$ Cf. idem, p. 430: "E, admitindo-se esses teoremas na ótica, haveria capacidade suficiente para tratar dessa ciência de maneira volumosa segundo uma nova maneira, não apenas ensinando as coisas que tendem à perfeição da visão, mas também determinando matematicamente todos os tipos de fenômenos de cores que possam ser produzidos por meio de refrações. Pois para fazê-lo não se requer nada mais do que descobrir as separações de raios heterogêneos e suas várias misturas e suas proporções em cada mistura".
} 
dos corpos, de acordo com seus diversos tamanhos, refletem raios de uma cor $e$ transmitem os de outra (...). E isso eu tomo como sendo o fundamento de todas as suas cores"10. Assim, afirma ele na sétima proposição, "a grandeza das partes componentes de corpos naturais pode ser conjecturada a partir de suas cores", e acrescenta: "não é impossível que microscópios venham, com o tempo, a ser aprimorados a ponto de se descobrir as partículas de corpos de que dependem suas cores, se é que já não chegaram, em alguma medida, a esse grau de perfeição"11. Com isso, Newton pretende ter desenvolvido um método para apreender o fenômeno das cores segundo um modelo matemático, relacionando as cores com propriedades quantitativas associadas aos corpos que interagem com os raios de luz.

No entanto, essa explicação puramente mecânica do fenômeno das cores, embora como dito, busque evitar o problema de sua transformação em uma sensação qualitativa, não permite que ele evada a discussão acerca da qualidade da própria luz, isto é, do suposto correspondente objetivo de nossas impressões luminosas. Ela depende, muito antes, de uma definição da luz como composta de corpúsculos. No próximo item veremos como, de certo ponto de vista, essa hipótese acerca da natureza da luz é o preço que Newton paga para contornar o problema da sensação.

No tempo de Newton, os cientistas estavam divididos quanto à natureza da luz. A maior parte apoiava então teoria defendida por Christiaan Huygens, segundo a qual a luz seria apenas onda, vibração em algum tipo de meio etéreo. Ambas as teorias, tanto a de Huygens como a de Newton, explicavam igualmente bem os fenômenos da dispersão e da refração. Enquanto os partidários de Huygens defendiam a teoria da luz como onda devido à falta de evidência de interferência dos raios de luz entre si, Newton argumentava que a luz tinha que ser corpuscular porque não se observava nela qualquer forma de difração, fenômeno que acompanha todo tipo de onda então observável ${ }^{12}$. Outra forte razão para Newton adotar a hipótese corpuscular era sua pretensão de construir uma teoria da refração análoga à sua teoria da gravitação: para ele, os corpúsculos de luz, ao

\footnotetext{
${ }^{10}$ Idem, p. 481; cf. p. 530.

11 Idem, p. 482, 485; cf. p. 491.

${ }^{12}$ A presente reconstrução da discussão entre Newton e os partidários de Huygens baseia-se no relato de BALDWIN, G. C. An introduction to Nonlinear Optics, p. 2.
} 
atravessarem corpos translúcidos, seriam desviados por uma força análoga à da gravidade, a qual agiria a distâncias mínimas ${ }^{13}$.

\section{c) O modelo mecanicista de sensação proposto por Newton}

O modelo mecanicista de compreensão da luz e das cores implica também uma hipótese acerca do modo como os estímulos luminosos são propagados a partir de nossos órgãos sensíveis para formar a sensação das cores. Essa concepção é resumida na décima segunda questão do terceiro livro da Ótica ${ }^{14}$, na qual Newton pergunta: "Os raios de luz, caindo sobre o fundo do olho, não excitam vibrações na tunica retina? Vibrações estas que, sendo propagadas ao longo das fibras sólidas dos nervos óticos para dentro do cérebro, causam o sentido da visão?". Semelhantemente, vemo-lo perguntar o seguinte na questão de número $28^{15}$, em meio a uma enumeração mais ampla de perguntas concernentes à estrutura íntima do universo e sua relação com Deus:

Não é o sensório [sensory] dos animais aquele lugar ao qual a substância sensitiva está presente, e para dentro do qual as espécies sensíveis [sensible species] das coisas são carregadas através dos nervos e do cérebro, e isso para que possam ser percebidas por meio de sua presença imediata para aquela substância? (...) Coisas estas de que apenas as imagens carregadas através dos órgãos dos sentidos para dentro de nossos pequenos sensórios [sensoriums] são lá vistas e contempladas [beheld] por aquilo que em nós percebe e pensa ${ }^{16}$.

É preciso notar, contudo, que, no início do terceiro livro da Ótica, de onde retiramos as citações acima, Newton interrompe a exposição para alertar ao leitor que, daquele ponto em diante, por não ter podido levar a cabo todos os experimentos por ele planejados, passará a apresentar suas considerações sob a forma de questões (queries), a serem investigadas por meio de pesquisas e

${ }^{13}$ Cf. NEWTON, I. Optics, p. 529 ss.

${ }^{14}$ Idem, p. 518.

15 Idem, p. 529

${ }^{16}$ Cf. também a questão 23 (idem, p. 522): "Não é a visão executada principalmente pelas vibrações desse meio [etéreo], excitadas no fundo do olho pelos raios de luz e propagadas através dos sólidos, translúcidos e uniformes capillamenta dos nervos óticos para dentro do local da sensação?". Na questão 16 (idem, p. 519), Newton busca confirmar sua hipótese aduzindo um fenômeno visual considerado "subjetivo", apontando sua analogia com a impressão luminosa: a pressão física no olho também nos faz ver manchas luminosas: "Não surgem estas cores de movimentos excitados no fundo do olho pela pressão e pelo movimento do dedo, os quais são em outros momentos excitados ali pela luz para causar a visão?". 
experimentos ulteriores ${ }^{17}$.

Mas, se Newton anuncia todas essas questões como meras propostas hipotéticas, sem pretensão imediata à verdade, qual seria, então, sua relação com a porção dogmática da Ótica? Nossa tese aqui é que justamente essas considerações mais especulativas de Newton, cuidadosamente reduzidas à categoria de "questões" propostas para incitar uma pesquisa ulterior, revelam, não obstante, a maneira como o físico pretende solucionar o problema da relação entre quantidade e qualidade no fenômeno das cores. Isso porque essas questões nos fornecem um indício de pressupostos necessariamente adotados por Newton para que este pudesse tratar objetiva e matematicamente da luz e de seus efeitos. Ora, sem a suposição tácita de que nossa sensação (qualitativa) das cores seria um efeito mecânico de vibrações (quantificáveis) ocasionadas pelo choque de certos corpúsculos de que a luz seria composta e propagadas através dos nervos, Newton se veria, antes de poder iniciar seu trabalho de matematização dos efeitos luminosos, diante do enorme problema - propriamente filosófico - da fundamentação da objetividade de todos esses fenômenos de cuja matematização ele se ocupa, isto é, da recondução das sensações qualitativas das cores a um fenômeno objetivo quantificável - problema este que, conforme veremos, será o ponto de partida da doutrina das cores goetheana e, na esteira desta, o cerne da teoria das cores desenvolvida por Schopenhauer.

\section{Goethe}

\section{a) Teoria e intuição}

A crítica de Goethe à teoria newtoniana das cores é, sem dúvida, como já dito no início, a parte menos valorizada de sua doutrina - e consequentemente também a menos lida e estudada. ${ }^{18}$ Longe, porém, de pretender realizar uma análise minuciosa dessa crítica e julgar a correção da mesma, queremos aqui apenas ressaltar seus pontos centrais, dos quais decorrem, em certa medida, as

\footnotetext{
${ }^{17}$ Cf. idem, p. 516.

18 Tanto que diversas edições das obras de Goethe, inclusive as de 1909 e 1949 que aqui utilizamos, não contêm a segunda parte do primeiro volume, isto é, a "Parte polêmica" dedicada à refutação da doutrina de Newton. Daí termos sido forçados a citar as suas passagens a partir da edição original de 1810.
} 
diferenças profundas que há entre os projetos de Goethe e Newton, a serem discutidas em seguida.

Embora Goethe não o tenha formulado precisamente desta maneira, pareceme lícito dizer, assim, em poucas palavras, que sua principal crítica a Newton, subjacente às diferenças mais concretas entre os projetos de ambos, é justamente que este último, em sua teoria das cores, não teria se atido seriamente à sua própria máxima hypotheses non fingo. É possível ver toda a concepção de Goethe sobre as cores como estando em uma relação estreita com essa crítica, isto é, como uma tentativa de alcançar um nível mais fundamental e imediato do fenômeno das cores, ignorado por Newton.

Segundo Goethe, a Ótica de Newton já parte de uma série de pressupostos e preconceitos acerca do fenômeno das cores, dos quais o principal teria consistido no tratamento da luz - em si um abstractum - como o único objeto de análise para a compreensão do mesmo, o que o levou a considerar a luz branca (ou melhor, a luz do Sol) um composto ou mistura de todas as luzes coloridas, que sempre já as contém. ${ }^{19}$ - Sim, veremos em seguida como o cerne da teoria das cores de Goethe, o famoso Urphänomen da oposição entre luz e escuridão, assim como a atenção dada por ele ao elemento fisiológico do fenômeno das cores, surge em grande medida como parte de uma proposta de apreender esse fenômeno de maneira mais fundamental, em uma universalidade da qual as aparições analisadas por Newton em seus experimentos comporiam apenas um fenômeno parcial, e que sua teoria, consequentemente, não teria sido capaz de alcançar.

No prefácio de Para a doutrina das cores, Goethe expressa a relação de sua doutrina com a newtoniana utilizando-se de uma metáfora:

\begin{abstract}
Comparamos a teoria das cores newtoniana com uma antiga fortaleza, que no início foi erigida por seu construtor com uma precipitação juvenil, mas que depois, segundo as necessidades do tempo e das circunstâncias, foi sendo aos poucos ampliada e equipada por ele, e não menos, por ocasião de contendas e animosidades, cada vez mais fortificada e guarnecida. / Assim procederam também seus sucessores e herdeiros ${ }^{20}$.
\end{abstract}

Dessa maneira, após inúmeras modificações e ampliações da construção, a

${ }^{19}$ Cf. GOETHE, J. W. Zur Farbenlehre (1810), §§ 19-22, p. 365 ss.

${ }^{20}$ Idem (1949), p. 12 s. 
fortaleza teria se tornado cada vez menos adequada para a habitação e cada vez mais ultrapassada em seu estilo e método de construção. Goethe prossegue:

\begin{abstract}
Não se trata aqui, pois, de um longo cerco ou de uma dúbia contenda. Encontramos, muito antes, esta oitava maravilha do mundo já como uma antiguidade abandonada, que ameaça desabar, e começamos imediatamente a demoli-la, sem mais, a começar por vigas e telhado, para que o Sol finalmente ilumine esse velho ninho de ratos e corujas e revele aos olhos do pasmo viajante a sua arquitetura labiríntica e desconexa, o estritamente provisório, o que foi forçado pelo acaso, o que foi rebuscado intencionalmente, o que foi remendado de maneira miserável.
\end{abstract}

No entanto, ressalta Goethe, apesar do estado lastimável do edifício da teoria newtoniana das cores, após aberto um novo espaço, "não é de modo algum nossa intenção encobri-lo e perturbá-lo com um novo edifício; queremos, muito antes, nos servir do mesmo para exibir uma bela sequência de múltiplas figuras".

Estas últimas palavras revelam-nos a diretriz metodológica fundamental característica do projeto de Goethe não apenas na sua doutrina das cores, mas em todas as suas incursões no pensamento científico. De maneira geral, podemos estabelecer como a característica central do modelo de ciência proposto por Goethe uma tenacidade em se ater à intuição [Anschauung], sem buscar refúgio precipitado em teorias e fórmulas abstratas - tanto metafísicas, como matemáticas, mecânicas ou corpusculares ${ }^{21}$. Pelo contrário, para ele o todo, o nível mais geral, deve ser alcançado por meio de um avanço gradual a partir dos fenômenos particulares, sem que jamais se deixe o solo da intuição ${ }^{22}$.

É claro que Goethe está ciente de que uma ciência puramente intuitiva é impossível - porque para ele a própria "intuição pura" é uma abstração e, no limite, uma ficção. "Todo ver [Ansehen]", diz Goethe, "passa a um observar [Betrachten], todo observar a um refletir [Sinnen], todo refletir a um associar [Verknüpfen], e assim pode-se dizer que já teorizamos em cada olhar atento que lançamos sobre o

\footnotetext{
${ }^{21}$ Cf. idem, p. $203 \mathrm{~s}$.

${ }^{22} \mathrm{Cf}$. idem, p. 68 s. Cf. também o eco dessa noção na queixa proferida logo ao início da introdução a Para a doutrina das cores (igualmente referente à recepção da obra de Newton): "encontramos que as pessoas preferem pôr de lado os fenômenos por meio de uma perspectiva teórica geral, de alguma espécie de explicação, em vez de se dar ao trabalho de conhecer o que é singular e construir um todo" (p. 19).
} 
mundo"23. A teoria é sempre uma forma de domínio da natureza, um jugo que lhe impomos; sem um tal jugo, porém, também não há conhecimento: o movimento incessante da natureza é avesso à forma do conhecimento, e o conhecimento é sempre uma forma de cristalização ou enrijecimento de sua fluidez originária. A questão não é, portanto, para Goethe, abdicar da teoria (isso seria impossível), mas impor à natureza um jugo que seja o mais suave possível, que menos se afaste de sua manifestação originária, a qual é sempre intuitiva ${ }^{24}$. Como ele diz no poema Atmosphäre, que abre uma série dedicada ao meteorólogo Luke Howard:

Die Welt, sie ist so groß und breit, Der Himmel auch so hehr und weit, Ich muss das alles mit Augen fassen, Will sich aber nicht recht denken lassen ${ }^{25}$.

Quer dizer: é sem dúvida difícil apreender em conceitos abstratos a vastidão que o mundo oferece ao nosso olhar. Mas o poema continua, e afirma:

Dich im Unendlichen zu finden, Mußt unterscheiden und dann verbinden; Durm danket mein beflügelt Lied Dem Manne, der Wolken unterschied ${ }^{26 .}$

Ou seja, apesar da dificuldade de se formular abstratamente a complexidade do mundo, essa formulação é imprescindível à nossa orientação no mesmo. Sim, diria Goethe, ela é até mesmo essencial ao nosso próprio modo de experienciar esse mundo, algo absolutamente inevitável já na experiência mais imediata, que não compõe, portanto, apenas um construto sobre a experiência, mas que está desde sempre embutido nela mesma. Desse modo, não é somente impossível experienciar o mundo sem teorizar sobre ele, mas essa própria experiência já é em si uma teorização: "O superlativamente elevado seria: compreender que tudo que é factual já é teoria. 0 azul do céu revela-nos a lei fundamental da cromática. Que não

\footnotetext{
${ }^{23}$ Idem, p. 11.

${ }^{24}$ Cf. SILVA, G. V. No limite da ciência, p. 29 ss.; WAGNER, K. Goethes Farbenlehre und Schopenhauers Farbentheorie, p. $146 \mathrm{~s}$.

${ }^{25}$ Em tradução livre: "O mundo é tão grande e basto, / O céu também soberbo e vasto, / Com olhos tudo devo apreender, / Mas não se permite bem compreender".

${ }^{26}$ Em tradução livre: "Para no infinito se orientar / Deve-se unir após cortar; / Meu canto voa agradecido / A quem nuvens tem distinguido".
} 
se busque nada por detrás dos fenômenos; eles mesmos são a doutrina"27.

A pretensão newtoniana de uma ciência do puramente objetivo não é apenas impossível para Goethe, mas é, antes de mais nada, um projeto unilateral, fruto de uma má compreensão das condições de nossa experiência: pois a própria intuição sobre a qual todo conhecimento se funda já é resultado de uma interação entre o objetivo e o subjetivo: "Pois na verdade empreendemos em vão expressar a essência de uma coisa. Percebemos efeitos, e uma história completa desses efeitos abarcaria, decerto, a essência da coisa em questão"28. Consequentemente, não se trata de conhecer a essência das coisas, mas "a relação dos objetos entre si", e especialmente "a relação do objeto mundano mais significativo, o homem, com os demais"29. 0 mundo tal como o experienciamos é um mundo de interações, das quais a mais primordial se dá entre esse mundo e o homem, através de seus sentidos $^{30}$. Também este seu ponto de vista sobre a natureza encontra-se expresso em passagens de sua obra poética, como por exemplo no poema Dem Physiker:

Natur hat weder Kern noch Schale, Alles ist sie mit einem Male ${ }^{31}$.

Esta abordagem de Goethe pode, em oposição ao objetivismo fisicalista de Newton, ser considerada fenomenológica, sobre o que teremos oportunidade de falar com mais detalhe mais adiante ${ }^{32}$.

Logo, a acusação de Goethe contra Newton não se dirige simplesmente ao fato de que este tenha teorizado sobre a natureza, mas antes que ele o tenha feito de maneira muito precipitada, sim, preconceituosa. Segundo ele, o renomado físico teria simplesmente (contrariamente à sua própria máxima) formulado uma hipótese demasiado precoce acerca da natureza da luz e das cores, dispondo, então, seus experimentos de acordo com essa opinião pré-formada. Na introdução a Para

\footnotetext{
27 GOETHE, J. W. Schriften zur Naturwissenschaft, "Maximen und Reflexionen”, p. 73.

28 GOETHE, J. W. Zur Farbenlehre (1949), p. 9.

${ }^{29}$ Idem, $§ 181$, p. 70.

30 Cf. SIMMEL, G. Kant und Goethe, p. 22 s.

31 Em tradução livre: "Não há casca ou imo algum, / A natureza é tudo em um".

32 Cf. SAFRANSKI, R. Goethe: Kunstwerk des Lebens, p. 493; SAFRANSKI, R. Schopenhauer und die wilden Jahre der Philosophie, p. 282. Também Wittgenstein utiliza-se desse termo para caracterizar criticamente o projeto goetheano para as cores.
} 
a doutrina das cores $^{33}$, Goethe compara os esforços de Newton por fundamentar experimentalmente sua teoria com os de um astrônomo que busca confirmar matemática e empiricamente a hipótese de que a Lua se encontraria no centro de nosso sistema planetário, violentando, assim, os fenômenos por meio de experimentos forçados e enviesados. 0 exemplo é bom, pois não é que esse astrônomo esteja errado: ele será, certamente, capaz de prever matematicamente os movimentos dos planetas e do Sol em torno da Lua - mas sua matemática será infinitamente mais abstrusa que a de Copérnico e seu modelo grosseiramente contra-intuitivo.

Ou seja, Goethe não contesta a teoria de Newton por considerá-la simplesmente errada, mas julga-a inadequada para apreender da maneira mais direta e inequívoca o fenômeno por ela descrito. A denúncia de Goethe é que a própria redução das cores aos graus de refratabilidade dos raios de luz, embora aparentemente contornando o problema de sua constituição, implica uma série de hipóteses acerca desses raios, como por exemplo a suposição de que a luz seria algo corpóreo ou que a luz branca seria uma mistura heterogênea de todas as cores homogêneas, hipóteses estas que, para Goethe, são desnecessárias e mesmo prejudiciais ao conhecimento sobre o fenômeno das cores ${ }^{34}$. A matemática, enfim, não é em si abominável, mas sim a "arrogância aristocrática" com que a teoria newtoniana se impõe por meio dela 35 .

\section{b) A noção de polaridade e a natureza da luz}

Dentre esses pressupostos, porém, queremos destacar um, que torna especialmente inteligível a diferença entre Goethe e Newton - e, como veremos mais adiante, também entre Goethe e Schopenhauer. Simultaneamente, ele nos permitirá avançar na exposição da concepção goetheana de ciência.

Em sua concepção da luz branca como uma luz heterogênea, composta de todos os raios "homogêneos" que produzem as cores particulares, Newton supõe,

\footnotetext{
${ }^{33}$ GOETHE, J. W. Zur Farbenlehre (1949), p. 19 s.

${ }^{34}$ Para a hipótese da luz ser composta de corpúsculos, cf. NEWTON, I. Optics, p. 524 ss., 529 s.; para a afirmação de que a luz branca seria uma mistura heterogênea de diversos raios coloridos cf. idem, p. 389, 404, 427, especialmente o enunciado do teorema 4 da quinta proposição da segunda parte do livro I da Ótica, que diz: "A brancura, assim como todas as cores cinzas entre branco e preto, podem ser compostas de cores, e a brancura da luz do Sol é composta de todas as cores primárias misturadas em uma proporção devida". 35 GOETHE, J. W. Zur Farbenlehre (1949), p. 14.
} 
de maneira absolutamente tácita, como algo auto-evidente, que a escuridão consistiria simplesmente na ausência de luz. No fundo, como veremos, pode-se dizer que é desse pressuposto que deriva a própria possibilidade de recompor a luz branca a partir das luzes coloridas. Correspondentemente, é também de sua negação que deriva a oposição de Goethe a essa possibilidade ${ }^{36}$.

Contra Newton e sua tese da decomponibilidade da luz branca, Goethe quer demonstrar que, na experiência mais imediata, a luz não vem ao nosso encontro como um composto. Pelo contrário, segundo ele, em nossa observação, ambas, a luz e a escuridão, o branco e o preto, constituem polos fundamentais extremos, simples, irredutíveis (e por isso não experienciáveis em sua pureza, mas sempre pressupostos e presentes em toda experiência), dos quais, muito antes, enquanto os mais simples, os fenômenos das cores devem ser derivados - e não o contrário, o branco ser uma composição das cores que existiriam originariamente e o preto simplesmente um nada, uma ausência de luz. Em vez de, como Newton, admitir de partida uma infinidade de raios de luz coloridos e tomar a escuridão como algo simplesmente nulo, Goethe pretende partir dessa oposição fundamental entre luz e escuridão para, a partir dela, derivar os fenômenos das cores ${ }^{37}$.

É importante observar como essa abordagem implica um projeto fundamentalmente distinto do de Newton. Enquanto este último resolve o antigo problema de como as cores se formam por meio da modificação da luz na refração, reflexão etc. ao simplesmente negar essa modificação e afirmar que os raios coloridos já estão contidos na luz solar, aparecendo devido a um mero deslocamento espacial (geometricamente determinável) dos mesmos, Goethe está interessado em descobrir as leis segundo as quais as cores se transformam e se misturam, passam de uma à outra - algo de que a teoria newtoniana, com seu procedimento analítico, não é capaz de dar conta ${ }^{38}$. Newton presume que as cores se encontram simplesmente prontas na luz, aguardando sua análise matemática, Goethe quer explicar como elas se constituem gradualmente a partir do fenômeno

${ }^{36}$ Cf. FRIEDLANDER, S. Warum verwarf der Farbenlehrer Goethe die Farbenlehre des Goetheaners Schopenhauer?, p. 288.

37 Sobre essa crítica a Newton cf. GOETHE, J. W. Zur Farbenlehre (1949), p. 115: "considerou-se até agora a luz como uma espécie de abstração, como um ente que subsiste e age por si, que em certa medida se condiciona a si mesmo e que, dadas as condições mínimas [bei geringen Anlässen], produz cores a partir de si mesmo".

38 Cf. WAGNER, K. Goethes Farbenlehre und Schopenhauers Farbentheorie, p. 98, 116 s. 
fundamental da interação entre luz e escuridão ${ }^{39}$.

Este projeto remete-nos imediatamente ao de sua doutrina da metamorfose das plantas. Também aqui Goethe está interessado nas metamorfoses da luz, e Newton ocupa na doutrina das cores uma posição análoga à da escola botânica originada em Lineu que, ao identificar sua ciência com a classificação de espécies e estruturas vegetais, destrói o movimento vivo da natureza que busca retratar ${ }^{40}$.

Para apreender essas metamorfoses, Goethe utiliza-se de uma noção que lhe é cara também em outras considerações sobre a natureza: o conceito de polaridade $^{41}$. No contexto da doutrina das cores, luz e escuridão compõem os extremos de uma polaridade fundamental: a primeira é, em sua pureza ideal, pura atividade; a última, pura inatividade e, por isso, uma limitação ${ }^{42}$. Dessa polaridade, por meio da interposição de um meio turvo (material), surge o primeiro par de cores complementares, igualmente opostas entre si: azul (a escuridão observada através de um meio turvo iluminado de maneira direta) e amarelo (a luz observada diretamente através de um meio turvo anteposto a um fundo escuro). À medida que o meio ganha em densidade, o azul torna-se mais claro e o amarelo mais escuro, mas simultaneamente essas cores adquirem gradualmente "uma aparência" [Schein] avermelhada, aproximando-as de seu ponto de culminação, que tende ao vermelho ${ }^{43}$. Assim formam-se, por meio do que Goethe chama de "elevação" [Steigerung], de um lado, o amarelo avermelhado [Rotgelb], depois o vermelho amarelado [Gelbrot]; do outro, o azul avermelhado [Rotblau] e o vermelho azulado [Blaurot] ${ }^{44}$. Por fim, a mistura desses dois polos elevados leva à culminação no vermelho puro, que para Goethe é o púrpura. 0 vermelho seria, portanto, o ponto

\footnotetext{
${ }^{39}$ Cf. GOETHE, J. W. Zur Farbenlehre (1949), p. 9: “As cores são atos [Taten] da luz; são seu agir e sofrer [Taten und Leiden]".

40 SILVA, G. V. No limite da ciência.

${ }^{41}$ Cf. GOETHE, J. W. Zur Farbenlehre (1949), p. 205; para uma perspectiva mais ampla acerca das aplicações do conceito de polaridade cf. o fragmento Polarität, p. $863 \mathrm{~s}$.

${ }^{42}$ Sobre o desenvolvimento desta noção nas obras de Goethe dedicadas às cores cf. WAGNER, K. Goethes Farbenlehre und Schopenhauers Farbentheorie, p. 123 s.

43 GOETHE, J. W. Zur Farbenlehre (1949), p. 189.

${ }^{44}$ É importante notar a escolha conceitual feita aqui por Goethe, que, ao invés de chamar as cores intermediárias simplesmente de "laranja" e "violeta", lhes dá os mencionados nomes compostos. Essa escolha reflete a pretensão de Goethe de apreender as cores intermediárias como passagens entre as Urfarben ("cores originárias" - amarelo, azul, vermelho e verde) e não como pontos definidos e isolados. O próprio círculo das cores [Farbenkreis] é, de fato, um ciclo, e as cores em conjunto são momentos do movimento de atração e repulsão polar entre luz e escuridão. 0 mesmo pode ser observado também na nomenclatura que Goethe cria no âmbito da botânica, conforme me apontou Fábio M. Nolasco em conversa pessoal.
} 
médio entre azul e amarelo por meio da assim chamada elevação. Por outro lado, uma simples mistura física de azul e amarelo puros levaria, através das cores intermediárias "azul esverdeado" e "verde azulado", de um lado, e "amarelo esverdeado" e "verde amarelado", de outro, até o "ponto de equilíbrio" ou indiferença entre ambos, o verde puro, uma cor que, apesar de composta, aparece para nós "como uma unidade, diante da qual não pensamos na composição"45. Desse modo, Goethe completa o círculo das cores, dando conta das passagens entre uma e outra, e sempre se atendo à perspectiva polar que adotara 46 .

Embora a oposição de luz e escuridão intermediada por meios turvos seja chamada em Para a doutrina das cores de Urphänomen da aparição de cores, o uso do esquema da polaridade - o qual, como dito, constitui o principal fio condutor de todos os trabalhos de Goethe no campo das ciências da natureza - permeia toda a parte didática da obra. Também o olho é um meio turvo e interage com luz e escuridão. Ele tem uma afinidade com a luz, uma natureza afim a ela, e a visão, longe de ser mero efeito mecânico, é para Goethe uma interação, sim, uma Wechselwirkung entre a luz e o olho ${ }^{47}$. Sim, o próprio olho, a nível fisiológico, revela uma atividade polarizada (o que terá grandes consequências para Schopenhauer) ${ }^{48}$. Também a nível químico o esquema se repete: aqui as cores são associadas à polaridade química entre acidez e alcalinidade dos elementos ${ }^{49}$.

Dessa diferença de concepção, isto é, desse modo de abordar o problema das cores, apoiado sobre pressupostos distintos, decorrem as principais incompatibilidades dos resultados da teoria das cores de Goethe com os da newtoniana.

Já mencionamos como do fato de a luz ser um dos polos da oposição fundamental do Urphänomen segue que ela tem necessariamente de ser simples, não podendo, portanto, conter em si, de antemão, todas as cores misturadas, como o queria Newton. Já do fato de as cores se constituírem por meio da interposição de

\footnotetext{
45 GOEHE, J. W. Zur Farbenlehre (1949), p. 188.

${ }^{46}$ Goethe desenvolve o esquema do presente parágrafo em diversas passagens ao longo do texto, mas apresenta-o de maneira mais sistemática nos §§ 689-707 (GOETHE, J. W. Zur Farbenlehre (1949), p. 186-190). Cf. também sua exposição na introdução, p. 22s. e na apresentação de Andreas Speiser (idem, p. 935 s.).

${ }^{47}$ Cf. GOETHE, J. W. Zur Farbenlehre (1949), p. 20 s.

${ }^{48} \mathrm{Cf}$. idem, $\S \S 5,8,33,38,40,48,50,60$ (p. 27 s., 34 s., 36, 38 s., 43).

${ }^{49}$ Cf. idem, p. 145.
} 
um meio turvo entre luz e sombra segue que estas, sendo, em certo sentido, sempre pontos entre esses polos, têm sempre que ser menos luz que a luz original;

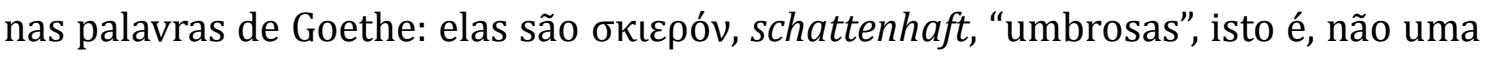
luz em si, mas antes uma espécie de "sombreamento", de fusão de luz e escuridão50. Disso segue, por sua vez, a famosa tese goetheana de que o branco jamais poderia ser composto da mistura de cores, a qual, mais uma vez, põe o poeta em oposição diametral a Newton ${ }^{51}$. Teremos oportunidade para tratar novamente desta questão mais adiante.

\section{c) Matemática e ciência da natureza, quantidade e qualidade}

A outra grande crítica recorrente à teoria das cores de Newton em Para a doutrina das cores refere-se ao uso da matemática como instrumento de comprovação e confirmação de uma hipótese. Vimos em nossa seção 1 que a redução dos fenômenos a leis matematizáveis não é apenas central para este último, mas que constituía efetivamente o objetivo de seu projeto para a ciência da natureza em geral. Para Goethe, porém, uma teoria física pode ser tão elaborada quanto se quiser a nível matemático, isso de modo algum lhe assegura sua adequação para descrever os fenômenos da natureza. (Lembremos do supracitado exemplo do astrônomo que pretende situar a Lua no centro de nosso sistema planetário por meio de cálculos intrincados e medições abstrusas.) Goethe atribui o estado da ciência das cores em sua época à coincidência de que tenha cabido justamente a um "grande matemático" (i.e. Newton) desenvolver uma teoria física das mesmas, a qual, porém, conforme já vimos, teria partido de pressupostos teóricos totalmente inadequados. Essa tendência a buscar quantificar as cores e suas relações derivaria também, segundo Goehte, do fato de que as demais leis da visão requerem a matematização, mas não as que regem as relações entre as cores $^{52}$.

Essa posição de Goethe levou muitos leitores seus a concluir que ele

\footnotetext{
${ }^{50}$ Cf. idem, p. 88, 186 s.

${ }^{51}$ Cf. idem, p. 158.

52 Cf. idem, p. 25: "Foi graças a uma peculiar conexão de circunstâncias que a doutrina das cores foi atraída para dentro do reino do matemático, de sua jurisdição [Gerichtsstuhl], aonde ela não pertence. Isso ocorreu devido ao seu parentesco com as demais leis da visão, para cujo tratamento o matemático tem realmente a vocação. Ademais, também porque um grande matemático trabalhou a doutrina das cores, e, como ele se equivocara enquanto físico, empregou toda a força de seu talento para conferir consistência a esse equívoco".
} 
pretendia efetivamente banir a matematização, a quantificação, da teoria das cores $^{53}$. E, de fato, não nos faltam passagens de Para a doutrina das cores que confirmem essa suspeita. Tomemos como exemplo a descrição da relação da doutrina das cores com a matemática, feita na quinta seção da parte didática de Para a doutrina das cores. Ali lemos:

Em especial, a doutrina das cores sofreu muito e seus avanços foram em grande medida impedidos por se tê-la mesclado com o restante da ótica, que não pode dispensar a medição [Meßkunst], enquanto que, na verdade, ela pode ser considerada de maneira totalmente isolada desse resto ${ }^{54}$.

No entanto, a quase proverbial aversão de Goethe à matemática não é, talvez, algo tão simples quanto se costuma pensar. A mesma seção donde provém a passagem supracitada, intitulada "Relação [da doutrina das cores] com a matemática", também deixa claro que Goethe, apesar de não poder "se gabar de nenhuma cultura nesse âmbito", valorizava, sim, a matemática como um instrumento útil55. Para Goethe, a matemática não é em si abominável, mas tem algo de "rígido e inflexível", sofre de uma certa "insuficiência"56. Ela não é equivocada, mas apenas unilateral, incapaz de exaurir a natureza, que, além de quantitativa, é também qualitativa ${ }^{57}$.

É nesse aspecto, principalmente, que o conceito de polaridade aparece para Goethe como superior à redução newtoniana do fenômeno das cores à quantidade. Embora o autor se utilize muito pouco das expressões "quantitativo" e "qualitativo" - o que já é indício de que seu pensamento pretende se mover para além dessa dicotomia -, uma anotação de seu espólio deixa bastante claro como a polaridade é

\footnotetext{
${ }^{53}$ Cf. BORNHEIM, G. Filosofia do romantismo, p. 96 apud SILVA, J. C. S. P. A. A gramática das cores em Wittgenstein, p. 260; idem, p. 230, nota 630.

${ }^{54}$ GOETHE, J. W. Zur Farbenlehre (1949), p. 195.

${ }^{55}$ Cf. idem, p. 195: "O autor do presente [escrito] buscou manter a doutrina das cores totalmente afastada da matemática, muito embora resultem com nitidez suficiente certos pontos em que o auxílio da arte de mensuração seria desejável".

${ }^{56}$ Idem, p. $203 \mathrm{~s}$.

57 Cf. a respeito STEINER, R. Einleitungen zu Goethes naturwissenschaftlichen Schriften, p. 237 ss.). 0 problema da relação entre quantidade e qualidade era importante para Goethe, conforme revela a seguinte passagem à p. 151 de GOETHE, J. W. Zur Farbenlehre (1949): "Esta [aparições cromáticas que ocorrem com líquidos coloridos em recipientes de diâmetro variado] é uma das aparições mais importantes da doutrina das cores, uma vez que experienciamos de maneira completamente apreensível uma relação quantitativa que produz uma impressão qualitativa em nossos sentidos".
} 
um esquema que se eleva para além da distinção entre quantidade e qualidade, que pode inclusive servir para representar a relação entre ambas. Simultaneamente, ela expõe em que sentido a matemática deve ser vista como unilateral:

0 matemático é remetido ao quantitativo, a tudo que pode ser determinado por meio do número e da medida, e, portanto, em certa medida, ao universo externamente cognoscível [äußerlich erkennbar]. Se, porém, o observarmos [i.e. esse universo], na medida em que nos é dada a capacidade para tal, com o espírito pleno e todas nossas forças, reconhecemos que quantidade e qualidade precisam valer como os dois polos da existência aparente [erscheinende Dasein]; é por isso que também o matemático eleva sua linguagem de fórmula até tal altura, para, na medida do possível, incluir no mundo mensurável e contável também o mundo imensurável. Por fim, tudo parece-lhe compreensível, apreensível e mecânico $(. . .)^{58}$.

Quer dizer: a única abordagem puramente matemática da natureza possível é o reducionismo de que Newton é exemplo. Este, porém, ao decompor o polo qualitativo de nossa experiência em quantidades mensuráveis, descaracteriza-o, traduz a qualidade para uma linguagem que não é capaz de expressá-la segundo sua natureza, "matando-a", em certo sentido, e, com ela, a vida da natureza. Já a polaridade põe em relação quantidade e qualidade, deixando a cada uma seu pleno direito como partes constitutivas da experiência, sem buscar reduzir uma à outra.

Por outro lado, vale lembrar que Goethe não retorna, com essa recusa da redução do conhecimento à fórmula matemática, a uma concepção aristotélicocartesiana de ciência como conhecimento ex causis. Já vimos que ele está muito antes interessado em fundar um modelo completamente novo de ciência, um modelo fenomenológico. Assim como Goethe não tem interesse em descobrir relações matemáticas entre as atividades da luz e o fenômeno das cores, não se trata para ele, tampouco, de encontrar na luz a causa da visão, nem de buscar a causa ou o fundamento da luz - o que o próprio Newton, inclusive, termina por fazer ao conceber a luz como composta de partículas, ao que ele aduz (no terceiro livro da Ótica, sempre sob a forma de "questões" [queries]) especulações sobre como Deus teria criado a matéria, entre outras de igual caráter etiológico e especulativo. A questão é muito antes conhecer apenas as condições fundamentais e

${ }^{58}$ GOETHE, J. W. Schriften zur Naturwissenschaft, "Maximen und Reflexionen”, p. 97. 
irredutíveis, porém imanentes à intuição, sob as quais as cores podem aparecer para nós 59 .

Mas teremos melhor oportunidade para nos aprofundarmos ainda mais nessa fenomenologia de Goethe a seguir, em sua comparação com a concepção schopenhaueriana. Concluímos aqui somente que Goethe não apenas pretende afastar da ciência das cores a remissão exclusiva ao âmbito ideal da matemática, mas também ao outro domínio, igualmente ideal, da especulação metafísica. Como dito, o Urphänomen - que permanece no âmbito da aparição intuitiva - deve ser o ponto culminante da experiência e, justamente por isso, também o seu limite:

Mas caso também se encontre um tal Urphänomen, permanece ainda o mal de não querer reconhecê-lo como tal, de buscarmos algo a mais por detrás dele e acima dele, enquanto que teríamos que admitir que aqui está a fronteira do olhar [Schauen]. Que o pesquisador da natureza deixe os Urphänomene permanecer em seu repouso e magnificência eternos $(. . .)^{60}$.

\section{Schopenhauer}

a) 0 pesquisador da natureza e o filósofo

No entanto, a passagem supracitada de Para a doutrina das cores não termina aí, mas prossegue da seguinte maneira:

(...) que o filósofo os acolha em sua região, e ele encontrará que não é em casos singulares, rubricas gerais, opiniões e hipóteses, mas no Urphänomen fundamental [Grund- und Urphänomen] que lhe é transmitido um material digno para o tratamento e a elaboração ulteriores ${ }^{61}$.

Para Goethe, o filósofo "toma da mão do físico um resultado final [ein Letztes], o qual se torna agora para ele um novo início [ein Erstes]. (...) Foi desejo do autor [i.e. de Goethe] aproximar a doutrina das cores do filósofo nesse sentido"62.

Ora, não podemos condenar Schopenhauer se este levou ao pé da letra o que

${ }^{59}$ Cf. WAGNER, K. Goethes Farbenlehre und Schopenhauers Farbentheorie, p. 144.

${ }^{60}$ GOETHE, J. W. Zur Farbenlehre (1949), p. 69.

${ }^{61}$ Idem, p. 69 s.

62 Idem, p. 194; cf. p. 193 s. 
escreve seu mestre na ciência das cores - mesmo que o resultado de seu tratamento filosófico da mesma não pareça ter agradado ao velho Goethe ${ }^{63}$. Como diz Safranski, Schopenhauer "exerce, sem dúvida, o papel de quem propagandeia, mas não diz o que Goethe quer ouvir [er redet Goethe nicht nach dem Munde]"64.

Para Schopenhauer, a Doutrina das cores seria "uma apresentação sistemática dos fatos"; "contudo", acrescenta, "ela permanece parada neles"65. Consequentemente, era natural que ele, enquanto filósofo, se sentisse no direito de, sim, efetivamente estimulado a elevar essa apresentação ao status de uma verdadeira teoria. Para ele, o serviço de Goethe na ciência das cores foi duplo: ele "rompeu a ilusão da falsa doutrina newtoniana e reconstituiu, por meio disso, a liberdade do pensamento sobre esse objeto"66. Schopenhauer pretende fazer uso dessa liberdade e elaborar sua própria teoria das cores baseada na doutrina goetheana, em conexão com o ponto de vista idealista que ele desenvolvera em sua dissertação de doutoramento Sobre a quadrúplice raiz do princípio de razão suficiente. Ao apresentar apenas "dados para a doutrina das cores", diz o filósofo, Goethe teria se abstido de "fornecer essa teoria mesma", não tendo estabelecido "nenhuma explicação da essência da cor", mas somente postulado a mesma "efetivamente como aparição, ensinando apenas como ela é constituída, mas não o que ela é"67. Para Schopenhauer, a vitória sobre Newton "só se torna plena quando uma nova teoria toma o lugar da antiga", e o filósofo chega a afirmar que Goethe teria dado indícios, em sua obra, de que ansiava por uma teorização de suas descobertas ${ }^{68}$. Schopenhauer conclui a introdução a Sobre a visão e as cores da seguinte maneira:

Complementar, então, a obra goetheana nessa perspectiva,

\footnotetext{
63 Desde cedo Goethe tem uma presença marcante na vida de Schopenhauer. É em grande parte graças a uma carta de recomendação redigida pelo poeta em 1809 que este pudera ingressar na então prestigiada instituição de Göttingen. Hübscher relata a forte impressão que Goethe deixou no jovem Schopenhauer, apesar de um primeiro contato bastante parco entre ambos, no salão de sua mãe, que era frequentado por grandes personalidades artísticas e intelectuais de Weimar, inclusive - e principalmente - Goethe. Quando, mais tarde, Schopenhauer retornou a Weimar, Goethe convidou-o a acompanhá-lo nos estudos e experimentos com as cores durante o inverno de 1813/14, uma relação que se estendeu pelos anos seguintes em correspondências que duraram até o início de 1816.

64 SAFRANSKI, R. Goethe: Kunstwerk des Lebens, p. 500.

65 SCHOPENHAUER, A. Über das Sehen und die Farben, p. 199.

66 Idem, p. 197.

${ }^{67}$ Idem, p. 198. Cf. também SCHOPENHAUER, A. Briefwechsel, carta 176 (11 de Novembro de 1815). 68 SCHOPENHAUER, A. Über das Sehen und die Farben, p. 199; cf. idem, p. 199 s.
} 
estabelecer in abstracto o mais elevado princípio sobre o qual todos os dados ali apresentados repousam e assim fornecer a teoria da cor no sentido mais estrito da palavra - eis o que a presente dissertação tentará fazer ${ }^{69}$.

Mas vimos que para o próprio Goethe "permanecer parado" em uma "apresentação sistemática dos fatos" estava longe de caracterizar seu trabalho como incompleto: apesar desse alegre aceno ao filósofo da passagem reproduzida mais acima, é fácil apreender a partir do projeto de Goethe que ele não esperava que sua "apresentação sistemática" fosse elevada a uma teoria em sentido clássico ${ }^{70}$. Inclusive, é bastante possível que ele pensasse, muito antes, com essas e outras convocações dos filósofos a levar adiante e elevar seu trabalho, muito mais em uma formalização filosófica à maneira de um Fichte - com a qual a concepção goetheana guarda semelhanças - do que na rígida sistematicidade quase obsessiva que caracteriza o pensamento de Schopenhauer. Ademais, Goethe não pretendia dizer "o que a cor é": se a natureza é um fluxo de relações, a cor não tem "essência" para além dos movimentos de sua constituição ${ }^{71}$. Já vimos que justamente essa avidez teórica foi o grande pretexto para sua recusa de Newton, e que Goethe queria, com total consciência, permanecer nos "meros fenômenos", vendo nisso não um simples trabalho preliminar, mas, pelo contrário, todo um novo modo de fazer ciência. Como Newton, afirma Karl Wagner, "também Schopenhauer era déspota", quer dizer, também ele ansiava por uma teoria definitiva em forma sistemática, o que para Goethe era prejudicial ao avanço de uma ciência ${ }^{72}$.

Arthur Hübscher dedica um capítulo de sua biografia filosófica canônica de Schopenhauer, Denker gegen den Strom: Schopenhauer: gestern - heute - morgen, à relação do filósofo com Goethe. Seu título, Ein unbequemer Schüler ("Um aluno incômodo"), já nos fornece o tom da narrativa desenvolvida por Hübscher, a qual se tornou quase um lugar-comum na pesquisa sobre a teoria das cores schopenhaueriana: o jovem Schopenhauer teria sido um aluno dedicado de Goethe

\footnotetext{
${ }^{69}$ Idem, p. 200.

${ }^{70} \mathrm{Cf}$. WAGNER, K. Goethes Farbenlehre und Schopenhauers Farbentheorie, p. 110, 150, 153.

71 Não podemos esquecer que estamos tratando do filósofo que negou o conceito de Wechselwirkung. - Sobre a influência de Fichte nos trabalhos de Goethe na ciência da natureza cf. a introdução de Andreas Speiser a Para a doutrina das cores (GOETHE, J. W. Zur Farbenlehre (1949), p. 937 ss.).

72 WAGNER, K. Goethes Farbenlehre und Schopenhauers Farbentheorie, p. 150 s. Sobre o despotismo teórico na ciência cf. GOETHE, J. W. Der Versuch als Vermittler von Objekt und Subjekt, p. 850.
} 
e um grande admirador seu, mas também um pensador independente, que buscou desenvolver - e em parte corrigir - a doutrina das cores goetheana. Goethe, porém, via nessa sua pesquisa sua grande contribuição à posteridade, atribuindo-lhe, inclusive, conforme é possível perceber a partir de anotações de sua maturidade, não apenas destaque absoluto entre seus trabalhos com a ciência da natureza (Goethe dedicou-se também a diversos outros estudos, como a mineralogia e a fisiologia vegetal, onde fez descobertas não sem mérito e significação), mas também um maior valor do que à própria produção literária e poética que o alçara ao status de personalidade histórica ${ }^{73}$. Devido a essa predileção, pois, argumenta Hübscher, Goethe teria se ofendido com a audácia de seu aluno e o excomungado do círculo de seus seguidores no que diz respeito à teoria das cores.

Para além dessa descrição de Hübscher, Rüdiger Safranski sublinha ainda, em sua biografia de Goethe, o outro lado da questão: o absurdo da presunção do jovem Schopenhauer que, em poucas semanas, quis corrigir e subordinar a uma teoria única, universal e correta o trabalho que ocupara Goethe durante décadas. Safranski cita uma passagem de uma longa carta de Schopenhauer a Goethe, datada de 11 de novembro de 1815, na qual ele expressa sua impaciência com a demora deste último para proferir seu juízo acerca da obra Sobre a visão e as cores - ou melhor, lhe dar sua bênção, já que Schopenhauer queria que Goethe se declarasse editor da mesma. Nela, Schopenhauer afirma: "Sei com certeza absoluta que forneci a primeira teoria das cores verdadeira, a primeira em toda a extensão da história da ciência"; e Safranski acrescenta: "Lembremo-nos de que para Goethe a 'Doutrina das cores' é a obra com que ele crê ter adquirido superioridade sobre muitos, aqui ele se sente como Napoleão no reino do espírito". ${ }^{74}$ Logo, o mais espantoso aqui não seria a recusa de Goethe, mas sim a desmesurada benevolência e brandura com que ele responde aos arroubos de arrogante prepotência de seu jovem aluno ao longo de toda sua breve correspondência, aluno este que, contrariando todo seu projeto de ciência, pretendia fazer de sua Doutrina das cores uma "teoria

\footnotetext{
${ }^{73}$ Cf. Goethe apud. SAFRANSKI, R. Goethe: Kunstwerk des Lebens, p. 498: "Sobre tudo que fiz como poeta (...) não tenho quaisquer pretensões. Viveram comigo excelentes poetas, viveram outros ainda mais excelentes antes de mim e haverão outros depois de mim. Que eu, porém, em meu século, seja o único que sabe o que é direito na difícil ciência da doutrina das cores, por isso me dou algum crédito, e tenho, pois, uma consciência de superioridade sobre muitos".

${ }^{74}$ SAFRANSKI, R. Goethe: Kunstwerk des Lebens, p. 502; cf. SAFRANSKI, R. Schopenhauer und die wilden Jahre der Philosophie, p. 282.
} 
verdadeira". - Por outro lado, admitindo a ingenuidade e conhecendo a obstinação do caráter do jovem filósofo, que parece não ter entendido (talvez pelas mesmas razões que o levaram a jamais compreender o projeto de Hegel, aliás o único outro grande filósofo partidário da teoria das cores goetheana) que Goethe buscava, com sua "mera exposição sistemática", uma nova forma de fazer ciência, é preciso confessar que não há nada mais natural para uma personalidade como a de Schopenhauer do que buscar avançar na pesquisa de seu mestre e conferir novos alicerces à sua doutrina.

\section{b) Deslocamento do Urphänomen para o âmbito fisiológico}

É claro que Hübscher não reduz sua reconstrução da relação entre ambos os pensadores a esse argumento puramente psicológico ${ }^{75}$. Ele também aduz (juntamente com a maior parte dos comentadores da questão), como motivo principal para a recusa de Goethe, o deslocamento do Urphänomen goetheano para o âmbito estritamente fisiológico operado por Schopenhauer em Sobre a visão e as cores $^{76}$.

De fato, é preciso conceder a Schopenhauer que Goethe chega a afirmar que as cores fisiológicas seriam "o fundamento de toda a doutrina"77 - mas, como diz Hübscher, o jovem filósofo toma essa afirmação de maneira demasiado literal, e termina por negar o Urphänomen de Goethe, que é, em última instância, objetivo (ou pelo menos não subjetivo no sentido idealista de Schopenhauer) ${ }^{78}$. Enquanto Schopenhauer quer reconduzir todo o fenômeno da aparição de cores ao elemento fisiológico, para Goethe, "o olho deve sua existência à luz"79, isto é, ele se encontra, como já vimos, em uma relação de reciprocidade com a luz, de modo que um só existe com e para o outro. Luz e olho formam uma das muitas dicotomias polares

\footnotetext{
75 Também Wagner reconhece a fraqueza deste argumento e irá buscar a razão do desentendimento em outra parte (cf. WAGNER, K. Goethes Farbenlehre und Schopenhauers Farbentheorie, p. 131 s.)

${ }^{76} \mathrm{Cf}$. também SAFRANSKI, R. Schopenhauer und die wilden Jahre der Philosophie, p. 276; WAGNER, K. Goethes Farbenlehre und Schopenhauers Farbentheorie, p. 110 s., 136 s.

77 GOETHE, J. W. Zur Farbenlehre (1949), p. 27.

${ }^{78}$ Cf. HÜBSCHER, A. Denker gegen den Strom: Schopenhauer: gestern - heute - morgen, p. 70.

${ }^{79}$ GOETHE, J. W. Zur Farbenlehre (1949), p. 20; cf. SILVA, J. C. S. P. A gramática das cores em Wittgenstein, p. 265 s. - Esta doutrina também reflete o princípio de Empédocles, segundo o qual cada coisa só pode ser conhecida pelo que lhe é semelhante. Cf. também o poema Wär nicht das Auge sonnenhaft: Wär nicht das Auge sonnenhaft, / Die Sonne könnt es nie erblicken (...) (em tradução livre: "Não fosse o olho algo solar, / 0 sol não poderia olhar (...)").
} 
que povoam o pensamento científico "fenomenológico" de Goethe ${ }^{80}$. Já para Schopenhauer, "a luz é apenas o sentido da visão observado objetivamente"81.

De um certo ponto de vista, porém, seria talvez lícito dizer que o deslocamento do Urphänomen para o âmbito fisiológico se baseia, em princípio, em uma argumentação semelhante àquela desenvolvida por Goethe para rechaçar a suposição que Newton fizera de uma luz pura e absoluta, independente de suas aparições. 0 projeto de Schopenhauer também é, em certo sentido, fenomenológico. Ele entende que prender-se a uma concepção objetivista da luz e das cores leva inevitavelmente ao atomismo mecanicista "cartesiano, sim, democrítico" em que desembocara a teoria de Newton. ${ }^{82}$ Conforme podemos observar tanto no texto de Sobre a visão e as cores, como no de Sobre a quadrúplice raiz do princípio de razão suficiente e no primeiro livro de $O$ mundo como vontade $e$ representação, a epistemologia de Schopenhauer é movida pelo mesmo pendor "fenomenológico" da doutrina de Goethe: a diferença aqui encontra-se no fato de que, para Schopenhauer, é evidente que o mais imediato do fenômeno das cores é sua percepção, e mesmo o jogo entre luz e trevas que compõe o Urphänomen de Goethe só ocorre - ao menos de maneira imediata para nós - no olho e para o olho. Esse seria, pois, o verdadeiro Urphänomen para Schopenhauer, que, por consistir no mecanismo de funcionamento do próprio olho, condiciona qualquer outro modo de ordenação objetiva das cores, seja segundo o modelo de oposição, mistura e intensificação do amarelo e do azul proposto por Goethe, seja segundo o de Newton, que ordena as cores em uma escala de acordo com os graus de refratabilidade dos raios que as provocam - pois qualquer que seja esse ordenamento objetivo da luz e da sombra, nós certamente o percebemos unicamente por meio da atividade de nosso olho: para além dele, diz Schopenhauer, podemos explicar os fenômenos apenas por meio de causas finais ${ }^{83}$.

\footnotetext{
80 Uma anedota interessante é reproduzida por alguns comentadores do assunto, segundo a qual Schopenhauer, ao tentar certa vez expor seu ponto de vista idealista segundo o qual a luz não existiria caso o olho não a visse, teria recebido como resposta de Goethe a seguinte exclamação: "Mas como! A luz deveria existir apenas na medida em que a vemos? Não! $O$ senhor não existiria caso a luz não $o$ visse!" (cf. a apresentação de Andreas Speiser a Para a doutrina das cores (GOETHE, J. W. Zur Farbenlehre (1949), p. 943); HÜBSCHER, A. Denker gegen den Strom: Schopenhauer: gestern - heute - morgen, p. 70).

${ }^{81}$ SCHOPENHAUER, A. Der handschriftliche Nachlaß, vol. 1, p. 244.

${ }^{82}$ SCHOPENHAUER, A. Über das Sehen und die Farben, p. 291.

${ }^{83} \mathrm{Cf}$. SCHOPENHAUER, A. Über das Sehen und die Farben, p. 275: “(...) como por exemplo que temos na cor um meio a mais para distinguir e conhecer as coisas"; idem, ibid: "Por consequência desta
} 
É evidente, contudo, a forte influência da filosofia transcendental kantiana sobre essa conclusão de Schopenhauer, a qual o afasta da "fenomenologia" no sentido goetheano que aqui buscamos explicitar, aproximando-o de uma espécie de idealismo que incorpora também as questões fisiológicas da cognição. Contra o objetivismo ingênuo de Newton, Goethe buscara, como já vimos, ater-se à intuição enquanto o âmbito entre o subjetivo e o objetivo, entre a causa e o efeito, isto é, como o campo em que se dão as relações entre ambos (isto é entre os aspectos fisiológico, físico e químico das cores); já Schopenhauer desloca o peso da questão para o polo oposto de Newton, o subjetivo, desequilibrando a balança que Goethe a tantas custas tentara manter horizontal ${ }^{84}$.

No fundo, Schopenhauer antecipa aqui, com esse deslocamento do Urphänomen para o âmbito fisiológico, mesmo que contra sua vontade (pois ele ainda se considera um partidário e defensor de Goethe), uma opinião bastante comum na interpretação da doutrina das cores goetheana: no geral, afirma-se, e principalmente a nível físico, ela estaria equivocada - no entanto, ela teria o mérito de ter introduzido seriamente a discussão sobre as cores a nível fisiológico, abrindo assim um novo campo de pesquisa para a ciência da visão ${ }^{85}$.

\section{c) A constituição do branco e a polaridade}

Para justificar esse deslocamento do Urphänomen, Schopenhauer aponta que Goethe não se esforça por unificar suas exposições sobre as cores fisiológicas e

derivação do Urphänomen goetheano de minha teoria o mesmo não merece mais ser chamado assim. (...) Da derivação do Urphänomen goetheano aqui fornecida segue também que a oposição física sempre precisa coincidir e concordar com a fisiológica".

${ }^{84}$ Cf. WAGNER, K. Goethes Farbenlehre und Schopenhauers Farbentheorie, p. 113, onde Wagner estabelece como um "princípio" da doutrina goetheana "que causa e efeito compõem juntos o fenômeno. O efeito fisiológico da cor no olho está contido no fenômeno conjunto [Gesamtphänomen] da aparição de cores". Cf. também idem, p. 140. Também Simmel (SIMMEL, G. Kant und Goethe) descreve o pensamento de Goethe como partindo de uma unidade originária, avesso à analítica.

${ }^{85}$ Cf. SAFRANSKI, R. Goethe: Kunstwerk des Lebens, p. 493. - Karl Wagner (Goethes Farbenlehre und Schopenhauers Farbentheorie, p. 154 s., 160 s.) relata como já Helmholtz tinha essa opinião, e que já a primeira resenha de Para a doutrina das cores argumentava "que, entendido corretamente, Newton e Goethe não estariam absolutamente em contradição, na medida em que não falam de uma mesma perspectiva, mas Goethe teria escolhido um ponto de vista fisiológico e Newton um físico e externo, a partir dos quais se revelam leis completamente distintas". Também o Wörterbuch der philosophischen Begriffe emite opinião semelhante sobre Goethe sob a rubrica Lichtempfindung (vol. II, p. 708 ss.). 
físicas ${ }^{86}$. Segundo o filósofo, isso fica bastante claro se considerarmos as oposições polares das cores propostas por Goethe em cada um desses momentos de sua exposição. Para este último, a nível fisiológico, os pares complementares das cores seriam os seguintes: amarelo e violeta, laranja e azul, vermelho e verde87; já na porção sobre as cores físicas Goethe pretende, como já dito, ver uma oposição fundamental entre amarelo e azul, cuja mistura formaria o verde (que não seria, portanto, uma cor fundamental) e de cuja "elevação" surgiriam gradualmente, do lado do amarelo, o laranja, e do lado do azul o violeta, que se encontrariam no ponto culminante, um vermelho intenso, "puro", o púrpura, o qual, por fim, fecharia o ciclo das cores. Ambas aparições - a fisiológica e a física - seriam manifestações distintas da polaridade com que a cor (e toda a natureza) sempre aparece para nós.

No entanto, diz Schopenhauer, Goethe não propõe, em nenhum momento, uma maneira de harmonizar essas perspectivas, mas compõe seu Urphänomen com referência à oposição física, não mais mencionando a polaridade fisiológica intrínseca ao funcionamento do olho. Logo, Schopenhauer, por meio dessa recondução do Urphänomen de Goethe à divisão da atividade fisiológica da retina (da qual trataremos em mais detalhe a seguir), não apenas o desloca do âmbito da natureza para o da percepção, mas ainda busca corrigir um suposto paradoxo na doutrina goetheana, amenizando a oposição física entre amarelo e azul estabelecida por Goethe como o fenômeno fundamental (afirmando tratar-se não de cores determinadas, mas de "classes de cores") e negando a sua polaridade em sentido rigoroso ${ }^{88}$.

Em Para a doutrina das cores, Goethe define a polaridade da seguinte maneira:

que tudo quanto deva aparecer, vir ao nosso encontro como fenômeno, precisaria indicar ou uma cisão [Entzweiung] originária

\footnotetext{
86 Cf. SCHOPENHAUER, A. Über das Sehen und die Farben, p. 198.

87 Cf. GOETHE, J. W. Zur Farbenlehre (1949), p. 39.

88 Cf. SCHOPENHAUER, A. Über das Sehen und die Farben, p. 276: "Por consequência disso tudo, a oposição física de amarelo e azul estabelecida por Goethe vale exclusivamente de modo geral, a saber, na medida em que amarelo e azul não significam aqui duas cores, mas duas classes de cores. (...) Mas se agora Goethe vai ainda mais longe e chama a oposição física de amarelo e azul de polar; então eu só poderia concordar com ele por meio de uma interpretação altamente forçada e preciso afastar-me dele. Pois, como mostra toda minha exposição, apenas as cores em sentido mais estrito têm uma oposição polar, enquanto afecções da retina, justamente cuja polarização, quer dizer, separação em atividades qualitativamente opostas, elas revelam. Afirmar a polaridade da luz significa absolutamente afirmar a divisão da luz".
} 
capaz de reunião, ou uma unidade originária que poderia chegar à divisão (...). Cindir o que é unificado, unificar o que é cindido, eis a vida da natureza ${ }^{89}$.

Já para Schopenhauer, a polaridade só pode significar a divisão de uma unidade primordial. Segundo sua concepção, "[t]oda polaridade precisa surgir de uma unidade", cuja polarização consiste na "diferenciação [Auseinandertreten] em atividades qualitativamente opostas". Logo, a dualidade não poderia ser originária, uma vez que coisas distintas desde o início, tendo origens diferentes, não teriam como nem por quê estar em oposição polar e aspirar à reunião. Este seria, porém, para Schopenhauer, o caso da pretensa polaridade entre luz e escuridão estabelecida por Goethe como Urphänomen ${ }^{90}$.

Disso segue que o esquema da polaridade é diferente em Goethe e Schopenhauer, conforme mostra o artigo de S. Friedlander publicado no Jahrbuch der Schopenhauer-Gesellschaft de 1932, cujo título é Warum verwarf der Farbenlehrer Goethe die Farbenlehre des Goetheaners Schopenhauer?. - Vimos como Goethe, contra Newton, supusera que as cores seriam produto da interação entre os polos originários da luz e da escuridão. Esta formaria, segundo Goethe, uma polaridade análoga à que observamos em fenômenos magnéticos e elétricos e que poderia ser representada pelos sinais + e -91. Ou seja, para ele, argumenta Friedlander, a escuridão não seria algo simplesmente nulo, mas um polo ativo oposto à luz. - Já Schopenhauer, ao localizar o Urphänomen na atividade da retina enquanto unidade qualitativamente dividida, teria também transformado com isso o conceito de polaridade herdado de Goethe e, como o próprio filósofo confessa em uma passagem de Sobre a visão e as cores, se reaproximado de Newton em certos aspectos, especialmente na questão da composição do branco a partir da mistura de cores - embora por uma via totalmente distinta ${ }^{92}$.

Enquanto a noção de polaridade goetheana, representada pelos sinais + e -,

${ }^{89}$ GOETHE, J. W. Zur Farbenlehre, p. 199.

90 SCHOPENHAUER, A. Über das Sehen und die Farben, p. $276 \mathrm{~s}$.

91 Cf. GOETHE, J. W. Zur Farbenlehre, p. 188, 199 ss. Sempre lembrando que isso que Goethe representa como uma operação matemática é, para ele, de fato um "negócio mais elevado" [ein höheres Geschäft], que não se deixa reduzir a números e grandezas (idem, ibid.).

92 Cf. SCHOPENHAUER, A. Über das Sehen und die Farben, p. 201: "assim, chegaremos, p. ex., especialmente a um ponto em que Goethe, que tem completa razão no todo, não obstante, errou, e Newton, que não tem nenhuma razão no todo, proferiu em certa medida a verdade, embora, com efeito, mais no que diz respeito às palavras do que ao sentido, e mesmo assim não inteiramente". 
situa os pares opostos de cores de tal modo que sua soma só pode aproximá-las do 0 (cinza), mas nunca do 1 (branco) ou do -1 (preto), o conceito de polaridade desenvolvido por Schopenhauer, segundo o qual as cores seriam frações da atividade originalmente unitária da retina, permite que sua soma resulte na reconstituição da atividade plena da mesma (p. ex.: $1 / 2($ vermelho $)+1 / 2$ (verde) = 1 (branco)).

Karl Wagner, por outro lado, contesta essa interpretação. Segundo ele, Goethe teria de fato parecido assumir em seu primeiro escrito sobre as cores (Contribuições à ótica, 1791-92) a escuridão como um polo ativo, oposto à luz. Em Para a doutrina das cores, porém, ele já a concebe inequivocamente como mera "limitação" [Schranke] - embora não tenha de modo algum se tornado dispensável como oposto da luz, unicamente de cuja interação surgem as cores. Segundo ele, a recusa da possibilidade da composição do branco a partir das cores proviria do desconhecimento, da parte de Goethe, de que as cores podem ser misturadas não apenas subtrativamente, mas também de maneira aditiva - o que Schopenhuaer já teria compreendido em sua teoria, ainda que não o tivesse formulado explicitamente. No mais, diz Wagner, Goethe tampouco distingue adequadamente o cinza propriamente dito da claridade reduzida - uma questão que, segundo ele, seguiria sendo polêmica até muito mais tarde ${ }^{93}$.

Seja como for, longe de ser uma questão secundária, como Schopenhauer quer fazer parecer, o problema da constituição do branco a partir das cores está ligado ao cerne das concepções de polaridade dos autores, as quais formam a base axiomática de seu tratamento das $\operatorname{cores}^{94}$.

\section{d) "Divisão qualitativa" da atividade da retina}

Vimos, até agora, como Schopenhauer, por diversos desvios, se reaproxima de Newton em pontos centrais de sua teoria, dando a Goethe plena razão em considerar o pensamento do jovem filósofo pernicioso para sua própria concepção: para começar, como Newton e diferentemente de Goethe, Schopenhauer quer fazer

\footnotetext{
93 Cf. WAGNER, K. Goethes Farbenlehre und Schopenhauers Farbentheorie, p. 123 ss.

94 Não podemos deixar de notar também que Schopenhauer retoma, com sua concepção de polaridade, o objetivo central do projeto newtoniano, o qual, como vimos, fora objeto de um juízo no mínimo ambíguo da parte de Goethe: Schopenhauer busca, com suas frações numéricas, justamente reintroduzir a possibilidade de um tratamento matemático das cores, tencionando matematizar o próprio modelo polar de compreensão da cor introduzido por Goethe.
} 
teoria; em segundo lugar, embora esteja claro que o filósofo, ao focar no elemento fisiológico, assume, neste aspecto, uma posição praticamente inversa ao objetivismo de Newton, vimos que esse deslocamento total da ênfase para o polo fisiológico redunda em uma fuga da hipóstase objetivista e fisicalista da luz em Newton para o outro extremo (o fisiológico), agora igualmente hipostasiado; por fim, vimos como esse deslocamento do Urphänomen goetheano para o âmbito fisiológico implicou uma mudança na noção de polaridade, a qual reverbera em todo o tratamento dado às cores e suas interrelações, e também na maneira como é concebida sua relação com a matemática. - Todas essas diferenças, conforme indicamos ao longo do texto, já foram apontadas anteriormente como razões para a branda, porém decidida recusa de Goethe do projeto de seu jovem aluno. Agora, porém, queremos ainda, para encerrar a presente seção, ilustrar como todas essas diferenças, ao afastarem Schopenhauer de Goethe, longe de aproximá-lo efetivamente de Newton, levam-no a dar um tratamento altamente original ao problema das cores, sua constituição e relação, o qual tem implicações filosóficas dignas de consideração, que inclusive permitem atar o trabalho de Schopenhauer sobre as cores ao todo de sua obra de maneira inédita ${ }^{95}$.

0 ponto central da teoria das cores schopenhaueriana encontra-se sem dúvida no $§ 5$ do segundo capítulo de Sobre a visão e as cores, intitulado "Atividade da retina qualitativamente dividida". Aqui, Schopenhauer pretende argumentar que a atividade de nossa retina, além de se dividir extensiva e intensivamente, também pode sofrer uma divisão qualitativa, da qual, justamente, dependeria o fenômeno da visão de cores.

Antes de mais nada, é necessário salientar a ousadia e a novidade deste pensamento do jovem Schopenhauer, uma vez que Kant postulara, em sua Crítica da razão pura, que a intensidade seria justamente a "quantidade da qualidade". Como compreender, então, que Schopenhauer agora distinga uma divisão intensiva e outra qualitativa da atividade da retina - e mais: que a divisão qualitativa seja, ela

\footnotetext{
${ }^{95}$ Cf. SILVA, G. V. (em elaboração). É interessante observar, quanto a isso, que curiosamente a teoria das cores não se encontra em conexão com a estética de Schopenhauer, mas se insere no contexto de sua teoria do conhecimento. Schopenhauer dá indicação específica dessa condição da cor em Der handschriftliche Nachlaß, vol. 1, p. 250, onde ele conta a qualidade (que ele especifica como sendo a cor), juntamente com a forma espacial, entre as formas de relação entre as coisas, que não seriam essenciais à ideia.
} 
mesma, quantificável, independentemente da intensidade?

Para melhor compreendermos essa façanha, resumiremos primeiramente o que Schopenhauer entende por "divisão extensiva" e "intensiva" da atividade da retina. A divisão extensiva refere-se simplesmente ao fato de que diferentes regiões da retina podem ser atingidas por diversos estímulos simultaneamente, isto é, não vemos apenas uma imagem uniforme de cada vez, mas um quadro composto de diversas cores e intensidades; a divisão intensiva da atividade da retina, por sua vez, quer dizer que ela é sensível à intensidade dos estímulos luminosos que recebe, graças a que distinguimos infinitos graus de luminosidade, da completa claridade à mais densa escuridão, do branco mais puro ao preto mais intenso, passando por todos os tons de cinza entre esses extremos ${ }^{96}$.

Já a divisão qualitativa da atividade da retina não geraria simplesmente tonalidades de cinza, mas permitiria que vejamos as coisas em cores. Sim, para Schopenhauer "a cor é a atividade da retina qualitativamente dividida"97. Referindo-se à construção da esfera ideal das cores concebida por Philipp Otto Runge, cujos polos seriam respectivamente o branco e o negro, e em cuja "linha equatorial" estaria o espectro das cores puras, que empalideceriam em direção a um polo e escureceriam em direção ao outro, Schopenhauer afirma que seria possível comparar as cores em sua intensidade mais plena, e assim estabelecer uma relação de intensidade entre elas que não dependeria de sua mistura com o branco ou o preto ${ }^{98}$. Segundo essa relação, o amarelo seria a cor mais intensa, e o violeta, a ele oposto, a mais fraca; no meio estariam, em ordem decrescente, o laranja, o vermelho e o verde, e o azul.

Dada essa relação, Schopenhauer conclui que seria possível determinar uma proporção entre as cores puras no que diz respeito à atividade da retina que elas evocam, chegando às frações que já mencionamos acima: supondo que a plena atividade da retina (que percebemos como branco) corresponda a 1 e a inatividade completa da mesma (o preto) ao 0 , o amarelo corresponderia a 3/4 da atividade da

\footnotetext{
96 Cf. SCHOPENHAUER, A. Über das Sehen und die Farben, p. 222 s.

97 Idem, p. 231.

98 Cf. idem, p. 227: "Neste ponto de sua maior energia, portanto, tal como representado pelo equador [da esfera cromática de Runge], cada cor tem uma aproximação íntima e essencial com o branco ou uma similaridade com a impressão da luz plena e, por outro lado, também uma obscuridade correspondente a ela em proporção inversa, isto é, uma aproximação com a escuridão". Para uma descrição mais detalhada da esfera de Runge cf. GOETHE, J. W. Zur Farbenlehre, p. 235 ss.
} 
retina e o violeta, seu oposto complementar, a 1/4 da mesma; o laranja, por sua vez, corresponderia a $2 / 3$ dessa atividade e o azul a 1/3; por fim, tanto o vermelho como o verde representariam $1 / 2$ da atividade da retina ${ }^{99}$. - É claro que há infinitas outras cores, cada uma com seu par complementar; mas, segundo Schopenhauer, estas seriam as principais justamente por representarem as frações mais simples. Assim, uma luz de certa cor evocaria uma certa porção qualitativa da atividade do olho, deixando outra inativa, a qual então, ao cessar o estímulo, se mostraria sob a forma da cor complementar do espectro fisiológico. As oposições entre as cores, assim como a explicação da tendência do olho a completar sua atividade por meio da evocação da cor complementar, derivam diretamente das reflexões de Goethe sobre as cores fisiológicas ${ }^{100}$ : a novidade aqui consiste, à primeira vista, unicamente na tentativa de dar um tratamento proporcionalquantitativo a essas relações polares.

Com isso, porém, Schopenhauer chega à estranha conclusão de que "a cor amarela é uma parte qualitativa muito maior dessa atividade [da retina] do que seu complemento, o violeta"101. Ora, mas o que seria uma "parte qualitativa maior", uma vez que não podemos aqui recorrer nem à representação da extensão, nem à da intensidade? Não seria esta uma expressão paradoxal? Não é qualquer parte já algo quantitativo? Essa é uma questão difícil de responder. Aparentemente, segundo o que pudemos analisar até aqui, Schopenhauer está, no fundo, apenas atribuindo uma intensidade essencial às diferentes cores - o amarelo, por exemplo, seria, em si, mais intenso, isto é, mais próximo do branco, que o azul ou o violeta.

No entanto, se atentarmos agora para a oposição entre vermelho e verde, a questão da divisão qualitativa da atividade da retina ganha uma nova dimensão, que novamente a afasta da mera intensidade, uma grandeza escalar, e não, como aparentemente é o caso na "divisão qualitativa", polar. Pois dissemos que, segundo as frações estipuladas por Schopenhauer, tanto o verde como o vermelho representariam $1 / 2$ da atividade total da retina - não obstante, são cores

\footnotetext{
${ }^{99}$ Cf. SCHOPENHAUER, A. Über das Sehen und die Farben, p. 229.

100 Cf. GOETHE, J. W. Zur Farbenlehre, p. 38 s., 43.

101 SCHOPENHAUER, A. Über das Sehen und die Farben, p. 226.
} 
completamente distintas entre si, sim, opostas, complementares ${ }^{102}$. Assim, Schopenhauer afirma, com referência à oposição entre verde e vermelho: "a divisão da atividade da retina é aqui qualitativa em grau eminente, o [elemento] quantitativo não se faz sensível aqui, como lá [no caso dos demais pares de cores complementares]"103.

Notando a aparente contradição de sua concepção, Schopenhauer explica-se em uma nota intercalada ao $§ 5$ de que ora tratamos. Reproduzimo-la aqui:

Não se deve ficar escandalizado com o fato de que, enquanto a divisão qualitativa da atividade da retina foi estabelecida à diferença da e em oposição à meramente quantitativa, falamos, não obstante, de metades iguais e desiguais na primeira, isto é, de uma relação quantitativa. Pois toda divisão qualitativa é simultaneamente quantitativa de um ponto de vista subordinado. Assim, toda cisão química [chemische Scheidung] é uma divisão qualitativa da matéria, em oposição à divisão mecânica meramente quantitativa: mas também ela é necessariamente ao mesmo tempo ainda uma divisão quantitativa, um dividir da massa enquanto massa, precisamente como a mecânica ${ }^{104}$.

Com isso, Schopenhauer desvincula-se da redução da qualidade à quantidade operada por Newton (e Kant), sem, contudo, abdicar da possibilidade de conferir um tratamento matemático ao fenômeno das cores. Pois segundo sua concepção as diferenças qualitativas entre as cores são sempre acompanhadas de proporções quantitativas por meio das quais podemos medi-las; no entanto, jamais se reduzem a elas: o quantitativo deve permanecer, mas de maneira subordinada.

Gostaríamos ainda de finalizar o presente trabalho com um breve e inevitavelmente - superficial panorama do pensamento sobre as cores desde o tempo do debate entre os autores de que tratamos. Nele, buscamos ressaltar as possíveis dimensões da influência que tiveram os pensamentos desses autores no

102 Cf. idem, p. 228: "Esse vermelho verdadeiro, puro, portanto, encontra-se exatamente à mesma distância do branco e do preto que seu complemento, o verde pleno. Logo, essas duas cores apresentam a atividade da retina dividida qualitativamente em duas metades iguais". 103 Idem, p. 228 s. 104 Idem, p. 231. 
direcionamento desse debate, assim como em que aspectos este pode ainda ter ultrapassado os mesmos e aberto novas dimensões da sempre problemática ciência das cores. Veremos que também o problema da relação entre quantidade e qualidade reaparece aqui de diferentes maneiras.

Fato é que a questão da visão das cores segue sendo até hoje complexa, e não chegamos a conclusões definitivas em nenhum dos campos que abarca. Sim, decerto, a ciência das cores transformou-se muito desde os tempos de Newton, Goethe e Schopenhauer. Todos os ramos de estudo sobre as cores, alguns inaugurados, outros enriquecidos por suas reflexões tão diversas, outros ainda criados posteriormente, multiplicaram suas pesquisas, refinaram seus métodos e critérios - apesar disso, não fomos capazes, até hoje, de esgotar nenhum deles completamente. Cada nova observação parece oferecer novos problemas e provocar novas especulações.

Enquanto, em nível macroscópico, a explicação da aparição física das cores a partir da refratabilidade dos raios de luz siga funcional, a ciência física avançou para muito além da representação newtoniana da luz. Já no início do século XIX Thomas Young descobriu que os raios de luz interferem, sim, uns com os outros, revalidando assim a hipótese (pré-newtoniana, defendida por Huygens) de que a luz seria, afinal, de qualidade ondulatória, e não corpuscular, como queria Newton. No entanto, esse retorno se impôs de maneira mais ampla somente em meados daquele século, parecendo firmar, assim, finalmente, uma base sólida para uma teoria quantitativa da luz ${ }^{105}$, especialmente quando Maxwell e Herz comprovaram a identidade qualitativa entre ondas eletromagnéticas e a luz. No início do século XX, com a quântica, novas descobertas acerca da interação entre luz e matéria levaram a física a avançar para representações absolutamente contra-intuitivas da luz, buscando unificar o comportamento ondulatório da mesma com sua troca descontínua ("quântica") de energia com a matéria naquilo que ficou conhecido como o "comportamento dual" da luz ${ }^{106}$. Desse ponto de vista, a luz seria algo ora compreensível como onda, ora como partícula, mas que em si, a nível quântico, seria alguma coisa que somos incapazes de representar de maneira adequada segundo nossas analogias macroscópicas.

${ }^{105}$ Cf. HELMHOLTZ, H. Vorträge und Reden I, p. 312 s.

106 Cf. BALDWIN, G. C. An Introduction to Nonlinear Optics, p. 2 s. 
Por outro lado, também já a partir da metade do século XIX a relação causal puramente mecânica entre os fenômenos físicos da luz e sua percepção subjetiva como cor, tal como proposta por Newton, encontrava-se em completo descrédito. Como já dito, a influência de Goethe nessa valorização do momento fisiológico da configuração das cores foi decisiva. Já Helmholtz, buscando harmonizar as duas perspectivas, teve que negar a coincidência entre o fenômeno luminoso puramente físico e a percepção subjetiva da cor, passando a considerar a última um mero "símbolo" do primeiro ${ }^{107}$. Essa perspectiva seguiu sendo elaborada intensamente por autores como Ewald Hering e Wilhelm Wundt ${ }^{108}$.

Como fruto dessa atenção voltada ao momento fisiológico envolvido no fenômeno cromático, a fisiologia do olho avançou para a identificação e categorização das células fotossensíveis da retina. Sabemos hoje que a maioria de nós, humanos, possui quatro tipos distintos dessas células: os bastonetes, usados em situações de baixa luminescência, e os cones, de três tipos distintos, responsáveis pelas impressões de cores.

Mas, embora a fisiologia tenha identificado essas diferentes células, ainda não encontramos solução teórica definitiva para muitos fenômenos da visão. Durante muito tempo, a teoria mais aceita foi a de Young-Helmholtz, que em sua versão atual postula que os bastonetes têm um só tipo e não distinguem nuances de cor, diferenciando apenas a intensidade luminosa, e cada um dos cones seria responsável por captar uma gama do espectro das cores (os cones S captam as ondas curtas, na região do azul, os $\mathrm{M}$ as ondas médias, que percebemos como verde, e os L as ondas longas, correspondentes à sensação do vermelho). Assim, a distinção entre intensidade e qualidade proposta por Schopenhauer encontraria um correspondente fisiológico na distinção entre bastonetes e cones. A teoria de Young-Helmholtz pretende dar conta do problema do "vermelho esverdeado" (observado pela primeira vez por Goethe) postulando que os cones M e L formam um tipo de "chave" por meio da qual percebemos um certo estímulo ou como verde, ou como vermelho. Caso o estímulo não seja interpretado nem como verde, nem como vermelho, ele passa ao terceiro cone (S), que identificará se ele corresponde ao azul. Se ele também não for azul, o cérebro interpretará o estímulo

107 Cf. HELMHOLTZ, H. Vorträge und Reden I, p. 317 ss.

${ }^{108}$ Cf. EISLER, R. Wörterbuch der philosophischen Begriffe, p. 708 ss. 
como amarelo. É baseado nesse modelo que funciona o sistema RGB (Red, Green, Blue) utilizado em televisões, por exemplo: estimulando o olho simultaneamente com verde e vermelho é-se capaz de produzir a sensação "ilusória" do amarelo (também há um comprimento de onda específico correspondente ao amarelo no espectro físico das cores).

No entanto, a teoria de Young-Helmholtz não dá conta de diversos fenômenos observáveis, como a tendência - também apontada por Goethe - do olho a reconstituir uma espécie de "equilíbrio" de sua atividade. Devido a essa e outras dificuldades - como por exemplo o fato de o preto só ser percebido de maneira intensa quando em contraste com cores claras ou branco -, a teoria dos "processos oponentes", formulada ainda no final do século XIX por Ewald Hering em termos de "substâncias visuais" [Sehsubstanzen], foi revisitada no século XX em tentativas de conferir um fundamento quantitativo àquilo que Hering postulara qualitativamente ${ }^{109}$. Segundo a teoria de Hering, que constitui um modelo efetivamente polar da visão, cada receptor não seria responsável por uma sensação única, mas por um processo visual de oposição: vermelho ou verde, azul ou amarelo e branco ou preto. Na escuridão, o olho retorna gradualmente ao seu estado de repouso, ao qual corresponde a sensação "cinza”. Isso explicaria por que as cores são intensificadas por meio do contraste. Contudo, também a teoria dos processos oponentes ainda tem status de hipótese e não parece dar conta de toda a gama do fenômeno de visão das cores.

Ainda no âmbito da fisiologia, a pesquisa genética desvendou a relação entre as células fotossensíveis da retina e os genes. 0 cone $S$ parece ser o mais antigo na escala evolutiva, e é encontrado em diversos organismos animais mais simples, estando codificado no cromossomo 7, um autossomo. Já cones M e L são mais recentes, fruto de uma duplicação gênica e encontram-se codificados no cromossomo X, que é um cromossomo sexual. Os bastonetes, por sua vez, parecem ter se desenvolvido nos mamíferos devido a uma fase de hábitos predominantemente noturnos na evolução. ${ }^{110}$ Essa descoberta não apenas permitiu explicar a ocorrência quase exclusiva da discromatopsia (daltonismo)

109 Cf. HURVICH, L. M. et al. An Opponent-Process Theroy of Color Vision; SILVA, J. C. S. P. A gramática das cores em Wittgenstein, p. 263.

110 Cf. BOWMAKER, J. K. Evolution of Colour Vision in Vertebrates. 
entre homens, mas também levou à suposição da possibilidade de indivíduos dotados de tetracromatismo, a qual ocorre apenas entre mulheres. Os indivíduos tetracromatas teriam hipoteticamente, devido a uma modificação em um de seus cromossomos $\mathrm{X}$, um cone a mais situado ou entre os cones $\mathrm{S}$ e $\mathrm{M}$, ou entre os cones M e L, o que lhes permitiria, ao menos potencialmente, distinguir nuances de verde/azul ou laranja que indivíduos normais são incapazes de perceber. Enquanto a maioria dos animais são mono ou dicromatas, há alguns que são tetra ou mesmo pentacromatas, e certos crustáceos (estomatópodes) chegam a possuir 10 ou mais receptores diferentes em seus olhos ${ }^{111}$. Como dito, porém, o atual estado de nossas teorias das cores não permite concluir com precisão em que esses modos diferenciados de visão se distinguiriam da tricromatismo mais comum.

É interessante, no entanto, que, nos casos documentados de indivíduos humanos supostamente tetracromatas, apesar de estes possuírem a base fisiológica para a percepção de um espectro muito mais nuançado de cores, eles nem sempre são capazes de distinguir mais cores do que a média. Pesquisas preliminares com esses indivíduos sugerem que é preciso também que eles desenvolvam esse seu potencial de algum modo - por exemplo exercendo uma atividade que estimule a distinção de cores -, e criem, de certa maneira, um vocabulário próprio para expressar sua percepção diferenciada.

Pesquisas históricas e antropológicas também revelam que mesmo grupos de base fisiológica "comum" podem desenvolver distinções entre cores que indivíduos de outras culturas são incapazes de fazer. Além do famoso exemplo dos povos Inuit, sabidamente capazes de distinguir dezenas de nuances de branco, há também o russo, que possui duas palavras para dois tipos distintos do que normalmente chamamos azul e que, aparentemente, devido a isso, são mais sensíveis a diferentes nuances dessa cor ${ }^{112}$. - Também o inverso pode ocorrer. Pesquisas histórico-filológicas sugerem que (com exceção dos egípcios) os povos da Antiguidade não possuíam um vocabulário para expressar com precisão a cor azul113. Trabalhos como o de Umberto Eco em How Culture Conditions the Colours

111 Cf. HOLBA, A. LUKÁCS, B. On Tetrachromasy; CRONIN, T. W. et al. Specialization of Retinal Funciton in the Compound Eyes of Mantis Shrimp.

${ }_{112} \mathrm{Cf}$. WINAWER, J. et al. Russian blues reveal effects of language on color discrimination.

113 Este fenômeno foi pela primeira vez documentado de maneira extensiva por William Gladstone, que publicou sua descoberta em 1858, no terceiro volume de seus Estudos sobre Homero e a época homérica. Segundo Gladstone, não apenas não há a cor azul em Homero, mas a categorização 
We See mostram como a classificação das cores percebidas pode variar radicalmente de uma cultura para outra, podendo incluir critérios diferentes que não costumamos levar em conta, como por exemplo o brilho ou "secura", "frescura" e "podridão"114.

Muito antes, porém, desses avanços da fisiologia e da antropologia, o filósofo Ludwig Wittgenstein já chamara atenção para a dimensão linguístico-cultural implicada em nossa percepção de cores. Em suas Anotações sobre as cores, Wittgenstein desenvolve uma crítica à abordagem "fenomenológica" goetheana, que pretende classificar as cores "puras", desligadas do contexto em que aparecem. Para ele, o problema da percepção de cores é primordialmente um problema conceitual: tratar-se-ia, antes de mais nada, de desenvolver uma gramática adequada para falar desse fenômeno com rigor ${ }^{115}$. Enquanto Wittgenstein, como todo bom pioneiro, termina praticamente por reduzir a dimensão do problema da percepção de cores ao elemento linguístico, outros estudiosos passaram, desde então, a levar mais a sério a relação entre a "estrutura" fisiológica da percepção e a "superestrutura" linguístico-cultural que a ela se sobrepõe, por assim dizer. Como exemplos especialmente frutíferos neste sentido são-me conhecidos o trabalho de Marshall Sahlins, Colors and Cultures, e o artigo de Umberto Eco mencionado acima, os quais buscam estabelecer uma abordagem semiótica da questão, na pretensão de inverter o sentido naturalista e fisiologista a que até hoje tende a interpretação do fenômeno das cores. Em Colors and Cultures, Sahlins argumenta que a constância descoberta por Berlin e Kay no desenvolvimento do vocabulário para as

homérica de "cores" em geral parece mais baseada em distinções quantitativas de luminosidade do que naquilo que hoje chamamos cor. Em um artigo de 1877 no periódico The Nineteenth Century intitulado The Colour-Sense, Gladstone resume suas descobertas e comenta outras pesquisas aparentadas, inclusive a de L. Geiger, que constatou a mesma ausência da menção da cor azul em outros textos canônicos da Antiguidade, como o Rigveda, o Velho Testamento e o Avesta do zoroastrismo, entre outros. No entanto, tanto Gladstone como Geiger vêem-se inclinados a supor, para explicar o fenômeno, que os povos da Antiguidade se encontrariam em outro estágio de desenvolvimento fisiológico do olho, e ainda tecem a hipótese de que esse desenvolvimento ocorreria segundo a ordem do espectro newtoniano das cores, em sentido descendente. É interessante observar, contudo, que Gladstone aponta um parentesco entre a concepção de cor de Homero e a doutrina das cores goetheana, uma vez que Homero somente categoriza as cores de acordo com sua proximidade em relação à luz ou à escuridão.

114 Também o Prof. Byron Hamman, que contribuiu com o presente texto por meio da sugestão de leituras, analisou em palestra ministrada no IA-Unicamp em 2015, o exemplo do conceito Asteca de luz, que difere radicalmente do nosso em seus critérios de categorização, possuindo, inclusive, códigos distintos a nível da linguagem falada e da representação gráfica de cores.

115 Cf. SILVA, J. C. S. P. A gramática das cores em Wittgenstein. 
cores - documentada na obra Basic Color Terms - possui um fundamento na demanda por critérios sociais de distinção. Para ele, a cor teria sua relevância na experiência primordialmente como um modo de categorização eficaz, e é apenas secundariamente que nosso vocabulário do universo cromático se torna de fato designativo.

Vemos, assim, como não apenas o pensamento de Newton, mas também as reflexões de Goethe e Schopenhauer contribuíram, embora de modo menos explícito e por vezes quase que anonimamente, com as diferentes mudanças que sofreu o campo da pesquisa sobre as cores, abrindo novos campos de investigação e suscitando novos problemas e questões, alguns dos quais permanecem ainda hoje em aberto. É possível que jamais cheguemos a uma teoria definitiva do fenômeno da visão de cores. E creio que a razão para isso é que a cor é mais que um fenômeno puramente físico, químico, fisiológico ou cultural. Ela encontra-se, como um dos elementos mais básicos de nossa experiência, em uma posição peculiar, que entrecorta todos esses campos - e talvez outros tantos mais ainda aguardando por ser devassados. Graças a essa sua posição, o problema da cor fornece um exemplo privilegiado de questões filosóficas profundas, tais como a da relação entre subjetividade e objetividade, qualidade e quantidade, da qual buscamos traçar aqui um esboço.

\section{Referências bibliográficas}

GOETHE, J. W. Zur Farbenlehre; Der Versuch als Vermittler von Objekt und Subjekt; Polarität in. Gedenkausgabe der Werke, Briefe und Gespräche, vol. 16. Beutler, E. (Ed.). Zurique: Artemis, 1949.

Aphorismen und Fragmente. in. Gedenkausgabe der Werke, Briefe und Gespräche, vol. 17. Beutler, E. (Ed.). Zurique: Artemis, 1949.

Zur Farbenlehre. Tübingen: J. G. Cotta'sche Buchhandlung, 1810.

Schriften zur Naturwissenschaft. in. Goethes Sämtliche Werke, vol. 39-40. Hellen, E. von der (Ed.). Stuttgart / Berlin: J. G. Cotta'sche Buchhandlung Nachfolger, 1902.

NEWTON, I. Mathematical Principles of Natural Philosophy (tradução de Andrew Motte); Optics in. Hutchins, R. M. (Ed.) The Great Books of the Western World, vol. 34. Chicago / Londres / Toronto / Genebra: Encyclopaedia Britannica, 1952.

SCHOPENHAUER, A. Über das Sehen und die Farben in. Arthur Schopenhauer: Sämtliche Werke, vol. 3. Löhneysen, W. von (Ed.). Stuttgart / Frankfurt am Main: Suhrkamp, 1986. 
Der handschriftliche Nachlaß in fünf Bänden. Hübscher, A. (Ed). Munique: DTV, 1985.

Der Briefwechsel. Nach: Arthur Schopenhauers sämtliche Werke 14., 15. und 16. Band: Ergänzungen und neu Aufgefundenes aus den Jahrbüchern der Schopenhauergesellschaft u. Arthur Schopenhauer Gesammelte Briefe. Berlim: InfoSoftWare, 2008.

BALDWIN, G. C. An introduction to Nonlinear Optics. Nova Iorque: Plenum Press, 1969.

BOWMAKER, J. K. Evolution of Colour Vision in Vertebrates. Eye, Londres, vol. 12, p. 541$547,1998$.

CRONIN, T. W. et al. Specialization of Retinal Function in the Compound Eyes of Mantis Shrimps. Vision Res., Inglaterra, vol. 34, no 20, p. 2639-2656, 1994.

CYSARZ, H. Goethe und Schopenhauer. Jahrbuch der Schopenhauer-Gesellschaft, Heidelberg, vol. XXIX, p. 03-23, 1942.

ECO, U. How Culture conditions the Colours we see in: Marshall Blonsky (Ed.) On Signs. Baltimore: The Johns Hopkins University Press, 1985.

EISLER, R. Wörterbuch der philosophischen Begriffe. Berlim: Ernst Siegfried Mittler und Sohn, 1910.

FRIEDLANDER, S. Warum verwarf der Farbenlehrer Goethe die Farbenlehre des goetheaners Schopenhauer? Jahrbuch der Schopenhauer-Gesellschaft, Heidelberg, vol. XIX, p. 287-290, 1932.

GEIGER, L. Zur Entwicklungsgeschichte der Menschheit. Stuttgart: J. G. Cotta'sche Buchhandlung, 1878.

GLADSTONE, W. E. The Colour-Sense. The Nineteenth Century, Londres, vol. 2, p. 366-388, Outubro de 1877.

HELMHOLTZ, H. Vorträge und Reden. Braunschweig: Friedrich Vieweg und Sohn, 1903.

HERING, E. Grundzüge der Lehre vom Lichtsinn. Berlim: Julius Springer, 1920.

$\begin{array}{lllll}\text { HOLBA, } & \text { A., } & \text { LUKÁCS, } & \text { B. } & \text { On }\end{array}$ (http://www.rmki.kfki.hu/ lukacs/TETRACH.htm)

HÜBSCHER, A. Denker gegen den Strom: Schopenhauer: gestern - heute - morgen. Bonn: Bouvier, 1982.

HÜBSCHER, A. (Ed.) Arthur Schopenhauer: Leben und Werk in Texten und Bildern. Frankfurt am Main: Insel Vlg., 1989.

HURVICH, L. M., JAMESON, D. An Opponent-Process Theroy of Color Vision. Psychological Review, EUA, vol. 64, no 6, p. 384-404, 1957. 
HUYGENS, C. Treatise on Light. in. Hutchins, R. M. (Ed.) The Great Books of the Western World, vol. 34. Chicago / Londres / Toronto / Genebra: Encyclopaedia Britannica, 1952.

SAFRANSKI, R. Goethe: Kunstwerk des Lebens. Munique: Carl Hanser Vlg., 2013. Schopenhauer und Die wilden Jahre der Philosophie. Munique / Viena: Carl Hanser Vlg., 2010.

SAHLINS, M. Colors and Cultures. Semiotica, Boston (?), vol. 16, 1, p. 01-22, 1976.

SIEBECK, H. Goethe als Denker. Stuttgart: Fr. Fromman, 1922.

SILVA, G. V. No limite da ciência: algumas considerações sobre a morfologia a partir da perspectiva da teoria da ciência de Schopenhauer. Revista Voluntas, Rio de Janeiro, vol. 4, no 2, p. 02-37, 2o semestre de 2013.

SILVA, J. C. S. P. A gramática das cores em Wittgenstein. 1999. 260 f. Tese (Doutorado em filosofia) - Unicamp, Campinas. 1999.

SIMMEL, G. Kant und Goethe. Berlin: Bad Marquad \& Co., 1906.

STEINER, R. Einleitung zu Goethes naturwissenschaftlichen Schriften. Dornach: Rudolf Steiner Verlag, 1987.

WAGNER, K. Goethes Farbenlehre und Schopenhauers Farbentheorie. Jahrbuch der Schopenhauer-Gesellschaft, Heidelberg, vol. XXII, p. 92-176, 1935.

WINAWER, J. et al. Russian blues reveal effects of language on color discrimination. Proceedings of the National Academy of Sciences of the United States of America, EUA, vol. 104, no 19, p. 7780-7785, Maio de 2007.

WITTGENSTEIN, L. Anotações sobre as cores / Bemerkungen über die Farben. Campinas: Editora da Unicamp, 2009. Apresentação, estabelecimento do texto, tradução e notas de João Carlos Salles Pires da Silva.

WUNDT, W. Grundzüge der physiologischen Psychologie. Leipzig: Wilhelm Engelmann, 1902. 